\title{
The Insurance Market of Natural Hazards for Residential Properties in Italy
}

\author{
Fabrizio Terenzio Gizzi*, Maria Rosaria Potenza, Cinzia Zotta \\ Institute for Archaeological and Monumental Heritage (IBAM), National Research Council (CNR), Potenza, Italy \\ Email: "f.gizzi@ibam.cnr.it
}

Received 7 January 2016; accepted 23 February 2016; published 26 February 2016

Copyright (C) 2016 by authors and Scientific Research Publishing Inc.

This work is licensed under the Creative Commons Attribution International License (CC BY). http://creativecommons.org/licenses/by/4.0/

(c) (i) Open Access

\begin{abstract}
Insurance is an effective complementary countermeasure for unexpected losses brought about by natural hazards. Coverage can be a useful tool considering in particular that public funds available to compensate for damages are limited and the consequences of catastrophes are becoming more severe over the time. Bearing this in mind, the authors performed a study aiming to clear up the main aspects and limits of the insurance market of natural hazards for residential properties in Italy. The opening sections of the paper give an overview of both the historical extreme events in Europe and Italy, and the reasons for the low insurance penetration rate in Italy. After that, the paper goes to the core of the research casting light upon the insurance market in Italy and examining the features and possible drawbacks of the available insurance covers. In this paper, the geophysical (seismic and volcanic) and hydrological (landslide and flood) hazards are analysed, and the residential stock is taken as a reference. After deepening in the local insurance market, the research focuses on the possible suggestions to stakeholders of how to increase the insurance penetration rate by taking advantage of the international experiences.
\end{abstract}

\section{Keywords}

Natural Hazards, Damages; Risk Perception, Risk Management, European Insurance Schemes

\section{Introduction}

Natural hazards are those events occurring by natural forces. They turn into disasters when their consequences are not easily recoverable such as loss of life or extreme damage to properties. Therefore, disasters threaten human society and its economic system and can lead to long-lasting financial and non-financial impact to the lives and the well-being of people affected [1]-[3]. This assertion is particularly suitable considering the dramatic

"Corresponding author. 
global increase in the number of events as well as their severity, with the latter being affected by the movement of people to disaster-prone areas, such as flood plains and coastal areas, the real estate vulnerability, the ineffectiveness of flood mitigation actions, and probably the climate change [4]-[7].

Italy is among a number of countries hit by natural disasters with a severe social and financial impact: earthquakes, floods, and landslides are responsible for mean annual losses equal to $0.2 \%$ of the national Gross Domestic Product [7].

The need of making economic tools useful to guarantee protection against losses from natural hazards in Europe has given rise to insurance schemes based on five main models [9]. For Italy, a free market supported by ex-post assistance by government is in force.

Due to the high historic losses in Italy and the low insurance penetration rate, the policy bases a speech on the opportunity and/or necessity to introduce a compulsory (or semi-mandatory) insurance system to relieve the State from heavy expenditure for the reconstruction of affected properties. This issue has been politically debated and has also been the object of a few non-promulgated designs of laws over the last two decades, from 1998 [10]. After the 2009 L'Aquila and 2012 Emilia earthquakes, the ticklish question has become topical again and another attempt to introduce an insurance plan was performed through the article No. 2: "Coperture assicurative su base volontaria contro i rischi di danni derivanti da calamità naturali" (Voluntary insurance coverage against damage caused by natural disasters) of the executive order No. 59/2012 dealing with "Disposizioni urgenti per il riordino della protezione civile" (Urgent provisions for the rearrangement of the National Civil Protection). The fundamental assumption of the article was to guarantee suitable, timely and uniform reparation and rebuilding actions considering that the State has limited economic resources to cope with the medium-long term consequences caused by natural hazards. However, the lack of an agreement between the policymakers in respect of the insurance scheme to be adopted (e.g. compulsory or semi-mandatory) has undermined the efforts.

Meanwhile these questions take up all the time of the policymakers. The private insurers follow with attention and fair caution the potential growth of the insurance market and put at customers' disposal a certain number of insurance policies "to protect" the house building from the consequences of natural hazards.

As being stated, the authors carried out a research aiming to cast light upon the features and limits of the insurance market for residential properties in Italy, in view of the establishment of a national insurance scheme possibly in the future. The lack of literature makes this study more important. As a matter of fact, we can only find glances for the Italian market in some papers or documents on the international insurance schemes [9] [11]-[13] or in some national studies (e.g. [14]) regarding the estimation of potential economic losses to the house buildings due to future earthquakes and floods, as well as regarding the analysis of possible insurance schemes to apply in Italy. Nevertheless, these studies do not exhaust the features of the situation in Italy; therefore it is necessary to go deeper. Bearing this in mind, this paper considers the policies available on the market comparatively, paying special attention to the typology of insurable perils, the insurability and exclusion rules, the premium to be paid to assure the properties, the use of incentive rules to obtain discounts on the premium, the amount of the deductibles, and the compensation time for damages. The analyzed hazards are the geophysical (seismic and volcanic) and hydrological (landslide and flood) ones. As for the real estate examined, we have considered the residential building (housings and condominiums).

The paper is divided into four main parts. The first provides an overview of the most important disasters and damage especially in Europe and Italy; the second deals with the analysis of the causes of the low insurance penetration rate in Italy with particular attention to the risk perception as well as the role of the Italian state aids; the third considers the features of the insurance market in Italy and the last examines the advantages and the drawbacks that the available coverings can imply and supply some possible policy suggestions for stakeholders (Italian institutions and insurance companies), also taking advantages of the international insurance schemes in force in other countries.

\section{Disasters in Europe and Italy: Overview}

In order to highlight the disaster's impact on human settlements in EU countries we briefly analyze some statistical data derived from one of the largest worldwide public databases on disasters: the Emergency Events Database (EM-DAT, Emergency Events Database, www.emdat.be last checked 10 September 2014).

EM-DAT covers a time span from 1900 to present and considers two disaster categories: natural and technological. The former one is subdivided into five subcategories: Geophysical (including seismic and volcanic), 
Meteorological, Hydrological (including landslide and flood), Climatological and Biological. The database provides information on the impact of disasters to people such as the number of people killed, injured, affected, left homeless and on the damages in relation to the date in which the disaster occurred (un-inflated US\$).

The catastrophes recorded in the database are approximately 13,000, 12\% of which happened in the EU countries. As a whole, the disasters killed around 33 million people, affected 7 billion people, and resulted in 170 million homeless and thousand billion of damages.

Comparing all the catastrophes that occurred over the last one hundred years in Europe, floods have been the most frequent among the extreme events with a mean frequency of around 5 events per year causing the highest percentage of homeless people (57\% of the total, about 2 million people) and the greatest losses in economic terms ( $33 \%$, about 112 billion of US\$).

The main cause of death is geophysical disasters, in particular earthquakes $(280,000$ people), followed by hydrological disasters (wet mass movements and floods) totally resulting in approximately 25,000 deaths. The earthquakes occurred in the Old Continent also caused 1,400,000 homeless and massive damages equivalent to 78 billion US\$.

Looking at a wider time-span of 2500 years, among the hundreds of strong earthquakes that caused heavy damages in Italy, three events that occurred during the 20th century are among the most relevant in terms of magnitude and number of people killed: on 28 December 1908 Calabria-Messina, 13 January 1915 Marsica and 23 November 1980 Irpinia earthquakes killed around a hundred thousand people in total [15].

The earthquake of 28 December $1908(\mathrm{Me}=7.1)$ is the most devastating event of the past century and one of the strongest earthquakes in Italy. The event damaged the regions of Sicily and Calabria. Dozens of towns were destroyed among which those of Reggio Calabria and Messina. This disaster resulted in the death of a number of people varying between 58,000 and 65,000 , an equal to $40 \%$ of the population estimated at that time [16]. Seven years after the great Messina earthquake, another massive earthquake $(\mathrm{Me}=7.0)$ wreaked havoc on some villages of the Fucino basin and the surrounding areas, causing more than 30,000 deaths and the destruction of numerous towns. Damage to monuments and houses were also recorded in Rome [15]. On 23 November 1980 Irpinia-Basilicata (Southern Italy) $(\mathrm{Me}=6.7)$ event caused serious damages in a wide area of the Campania and Basilicata regions causing approximately 2900 deaths. Fifteen locations were almost destroyed and dozens others suffered serious losses and housing damage [17].

Paying attention to the hydrological disasters (floods and wet mass movements) listed in the EM-DAT database, we can see that the EU countries mostly affected are: Russia, Italy and France followed by countries of Central and Eastern Europe. Italy, holds an adverse record of deaths $(3,600)$ in Southern Europe and a devastating record in Europe in terms of economic losses (about 24 billion of US\$) and number of homeless people (about 1.5 million of people).

Speaking about floods, the event that resulted in the majority of casualties (322) was the flash flood on 25-26 October 1954 in Salerno (Southern Italy) [4]. The most recent severe flash flood occurred on 4-5 May 1998 in Sarno (Campania, Southern Italy) where 157 people were killed by the consequent mudflow [18]. In respect of mass movements, one of the most disastrous landslides that hit the Italian territory occurred on 9 October 1963 in the Vajont Valley (northern Italy): millions of cubic meters of rock and debris detached from one side of the Valley slipped into a dam lake. The rockslide generated water waves that overflowed the dam and the town of Longarone, and four villages were also shattered. This event led to almost 2000 people deaths and a large number of injuries [19] [20].

\section{Reasons for the Low Insurance Penetration Rate in Italy}

In spite of the severe consequences caused by natural disasters, insurance penetration is very low in most European countries, including Italy. While the penetration rate for storm is quite high in most states, the rate reduces for floods and earthquakes; penetration rate is high (90\%) only in countries such as Belgium, Ireland, France, and the United Kingdom where coverage is a mandatory extension to the basic property policy. Italy, together with Bulgaria and Greece, stand out among the EU members due to the very low $(<10 \%)$ insurance penetration rate [13]; in Italy, coverage is offered as an optional endorsement to fire insurance contracts (Table 1). To be more specific, the Italian regions where insurance companies are most exposed to natural catastrophes, as to businesses and residential properties, are the Northern ones where, therefore, the penetration rate is higher [21]. 
Table 1. Insurance plans on natural disasters in Europe and Turkey... (Av = Avalanche; $\mathbf{C y}=$ Cyclone; $\mathbf{D h}=$ Drought; $\mathbf{E q}$ Earthquake; Fl = Flood; FF = Forest Fire; Fi = Fire; Fr = Frost; H/HS = Hail/Hail Storm; Ls = Landslide; Mt = Meteorite; $\mathbf{S s}=$ Subsidence; $\mathbf{S t}=$ Storm; $\mathbf{S W}=$ Snow Weight; $\mathbf{T n}=$ Tornado; $\mathbf{T s}=$ Tsunami; $\mathbf{V E}=$ Volcanic Eruption; OvR $=$ Overall Rate; -- = No data or not applicable). The last four columns report the penetration rate for some hazards or the rate estimated altogether for them. Data are drawn by the following sources [12]-[14] [25]-[32].

\begin{tabular}{|c|c|c|c|c|c|c|c|c|c|}
\hline Country & Insurable risks & Insurance rules & Pricing & $\begin{array}{c}\text { Compensation } \\
\text { limits/ } \\
\text { Deductibles }\end{array}$ & State role & $\begin{array}{c}\text { Eq } \\
\text { Rate } \\
(\%)\end{array}$ & $\begin{array}{c}\text { Fl } \\
\text { Rate } \\
(\%)\end{array}$ & $\begin{array}{c}\text { St } \\
\text { Rate } \\
(\%)\end{array}$ & $\begin{array}{l}\text { OvR } \\
\text { rate } \\
(\%)\end{array}$ \\
\hline Austria & $\begin{array}{l}\text { All hazards except } \\
\text { volcanic eruptions }\end{array}$ & $\begin{array}{l}\text { Optional. } \\
\text { Protection } \\
\text { against storm } \\
\text { is included in } \\
\text { households' } \\
\text { insurances }\end{array}$ & $\begin{array}{c}\text { The policy } \\
\text { price is free } \\
\text { and } \\
\text { risk-based }\end{array}$ & $\begin{array}{l}\text { Maximum } \\
\text { indemnity up to } \\
50 \% \text { of the } \\
\text { capital insured } \\
\text { or a fixed amount } \\
\text { ranging from } \\
3.700 € \text { to } \\
10.000 €(\mathrm{~F}) \text {. } \\
\text { Limit is about } \\
7.500 € \text { for } \\
\text { household }(\mathrm{Eq})\end{array}$ & $\begin{array}{l}\text { The Disaster } \\
\text { Fund supports } \\
\text { the Länder } \\
\text { since } 1966 \text { in } \\
\text { covering } \\
\text { the losses }\end{array}$ & 5 & 18 & 90 & -- \\
\hline
\end{tabular}

\begin{tabular}{|c|c|c|c|c|c|c|c|c|c|}
\hline Belgium & Eq-Fl-H-Ls-Ss-St-SW & $\begin{array}{l}\text { Semi-compulsory } \\
\text { (fire insurance } \\
\text { contracts) }\end{array}$ & $\begin{array}{l}\text { The policy price } \\
\text { is free except } \\
\text { when intervenes } \\
\text { the Bureau de } \\
\text { Tarification. This } \\
\text { was created to } \\
\text { specify the rules } \\
\text { to be followed to } \\
\text { fix the premiums } \\
\text { in case they are } \\
\text { too high or in } \\
\text { case of properties } \\
\text { not covered by } \\
\text { the market }\end{array}$ & $\begin{array}{l}\text { Deductibles } \\
\text { are indexed to } \\
\text { inflation } \\
(1.114,45 € \\
\text { in } 2010) \\
(\mathrm{F}, \mathrm{St}, \mathrm{Eq})\end{array}$ & $\begin{array}{l}\text { A public-private } \\
\text { partner-ship } \\
\text { is active. The } \\
\text { Caisse Nationale } \\
\text { des Calamites } \\
\text { guarantees the } \\
\text { indemnity } \\
\text { beyond the } \\
\text { limits fixed } \\
\text { by law }\end{array}$ & 90 & 90 & 90 & -- \\
\hline Bulgaria & Eq-Fl-H-Ls-St-SW & $\begin{array}{l}\text { The coverage is } \\
\text { offered as an } \\
\text { optional } \\
\text { extension in } \\
\text { basic } \\
\text { homeowners } \\
\text { contracts }\end{array}$ & $\begin{array}{l}\text { The policy } \\
\text { price is free: } \\
\text { flat for flood } \\
\text { and storm, } \\
\text { risk-based } \\
\text { for earthquake } \\
\text { for which the } \\
\text { premium is } \\
\text { about } 70 €\end{array}$ & $\begin{array}{l}\text { No limits }(\mathrm{F}, \mathrm{St}) \\
\text { Deductibles do } \\
\text { not exceed } 2 \% \\
\text { of the insured } \\
\text { value and many } \\
\text { companies do } \\
\text { not apply any } \\
\text { deductible. } \\
\text { Policies usually } \\
\text { cover } 85 \% \\
\text { of the insured } \\
\text { value (Eq) }\end{array}$ & -- & 5 & 5 & 5 & -- \\
\hline Cyprus & $\begin{array}{c}\text { All, except } \\
\text { Dh-Ls-Ss-SW }\end{array}$ & $\begin{array}{l}\text { Optional. } \\
\text { Covering as an } \\
\text { add-on of } \\
\text { fire policies }\end{array}$ & $\begin{array}{l}\text { The policy } \\
\text { price is free }\end{array}$ & -- & None & -- & -- & -- & -- \\
\hline $\begin{array}{c}\text { Czech } \\
\text { Republic }\end{array}$ & All & $\begin{array}{l}\text { Policies are on } \\
\text { voluntary basis. } \\
\text { Insurance against } \\
\text { floods is offered } \\
\text { as an extension } \\
\text { of property } \\
\text { insurance. } \\
\text { Insurances } \\
\text { against } \\
\text { earthquakes and } \\
\text { storms are often } \\
\text { bundled within a } \\
\text { base contracts }\end{array}$ & $\begin{array}{c}\text { The policy price } \\
\text { is free and } \\
\text { risk-based }\end{array}$ & $\begin{array}{l}\text { Some contracts } \\
\text { have compensa- } \\
\text { tion limit }(\mathrm{F}, \mathrm{Eq})\end{array}$ & $\begin{array}{l}\text { Losses for } \\
\text { properties not } \\
\text { covered by } \\
\text { private } \\
\text { insurance } \\
\text { have often } \\
\text { been covered } \\
\text { by ex-post } \\
\text { compensation } \\
\text { by the State }\end{array}$ & 50 & 50 & 50 & -- \\
\hline
\end{tabular}




\section{Continued}

\begin{tabular}{|c|c|c|c|c|c|c|c|c|c|}
\hline Denmark & $\begin{array}{c}\text { Cy-Ff-Fl-Fr-H- } \\
\text { Ls-Ss-SW }\end{array}$ & $\begin{array}{c}\text { Optional for all } \\
\text { except for } \\
\text { seawater flood } \\
\text { which is } \\
\text { semi-compulsory. } \\
\text { Policies can be } \\
\text { stipulated as an } \\
\text { extension of fire or } \\
\text { basic insurance } \\
\text { contracts }(\mathrm{Eq} / \mathrm{Fl})\end{array}$ & $\begin{array}{l}\text { Risk-based for } \\
\text { earth-quake } \\
\text { and storm, flat } \\
\text { for floods }\end{array}$ & $\begin{array}{l}\text { Deductible of the } \\
\text { minimum } 700 \\
\text { to a maximum of } \\
1350 € \text { as for } \\
2010 \text { depending } \\
\text { on extension of } \\
\text { the housings }(\mathrm{F}) \text {. } \\
\text { Depends on the } \\
\text { policies }(\mathrm{St} / \mathrm{Eq})\end{array}$ & $\begin{array}{l}\text { The State by } \\
\text { Storm Council } \\
\text { supplies a } \\
\text { guarantee if the } \\
\text { charge collected } \\
\text { by the insures } \\
\text { are insufficient } \\
\text { to cover the } \\
\text { losses caused by } \\
\text { seawater flood. }\end{array}$ & -- & -- & 90 & -- \\
\hline Estonia & $\begin{array}{l}\text { All, except } \\
\text { Eq-Ls-VE }\end{array}$ & Optional & $\begin{array}{l}\text { The price is } \\
\text { free and } \\
\text { risk-based }\end{array}$ & & None & -- & -- & -- & -- \\
\hline Finland & $\begin{array}{c}\text { All, except } \\
\text { Dr-Eq-Fr-VE-Ss- }\end{array}$ & $\begin{array}{c}\text { Optional } \\
\text { Storm risk is } \\
\text { insured in most } \\
\text { household } \\
\text { content policies } \\
\text { (St) }\end{array}$ & -- & -- & $\begin{array}{l}\text { Prevention } \\
\text { measures. } \\
\text { Public funds } \\
\text { were used to } \\
\text { compensate } \\
\text { losses caused by } \\
\text { strong extreme } \\
\text { events of the past. } \\
\text { A recent law } \\
\text { forbid the state to } \\
\text { cover the losses }\end{array}$ & -- & 18 & 90 & -- \\
\hline France & All & $\begin{array}{l}\text { Semi-compulsory } \\
\text { extension of basic } \\
\text { policies (fire, and } \\
\text { all properties } \\
\text { damage, including } \\
\text { car policies) }\end{array}$ & $\begin{array}{l}\text { The policy } \\
\text { price is } \\
\text { calculated on a } \\
\text { flat rates fixed } \\
\text { by the State } \\
\text { and depending } \\
\text { on typology } \\
\text { of real estates }\end{array}$ & $\begin{array}{l}\text { Do } \\
\text { No } \\
\text { compensation } \\
\text { limits but } \\
\text { deductibles. } \\
\text { For property of } \\
\text { domestic use } \\
380 € \text {. The } \\
\text { deductibles may } \\
\text { be increased } \\
\text { depending on the } \\
\text { number of claims } \\
\text { over the years. } \\
\text { (F, Eq, Dr) }\end{array}$ & $\begin{array}{l}\text { The State } \\
\text { founded the } \\
\text { Caisse Centrale } \\
\text { de Reinsurance to } \\
\text { support the } \\
\text { insurance } \\
\text { companies to } \\
\text { guarantee the } \\
\text { natural risks } \\
\text { (reinsurance). } \\
\text { The Caisse } \\
\text { offers to the } \\
\text { private insurance } \\
\text { market a flat } \\
\text { reinsurances rate. } \\
\text { The State } \\
\text { guarantees with } \\
\text { unlimited founds } \\
\text { the financial } \\
\text { capacity of the } \\
\text { Caisse }\end{array}$ & 90 & 90 & 90 & -- \\
\hline Germany & All, except Dr & $\begin{array}{c}\text { Optional extension } \\
\text { of home insurance. } \\
\text { Recently a } \\
\text { proposal for } \\
\text { a compulsory } \\
\text { flood insurance } \\
\text { was rejected by } \\
\text { a committee of } \\
\text { experts assembled } \\
\text { by Conference of } \\
\text { German Finance } \\
\text { Ministers (FMK) }\end{array}$ & $\begin{array}{l}\text { The policy } \\
\text { price is free } \\
\text { and risk-based. } \\
\text { There are } \\
4 \text { risk zones. }\end{array}$ & $\begin{array}{c}\text { No standard } \\
\text { deductibles } \\
(\mathrm{Eq}, \mathrm{F}, \mathrm{St})\end{array}$ & $\begin{array}{c}\text { Germany } \\
\text { compensated } \\
\text { the losses with } \\
\text { public funds in } \\
\text { the past. Now, } \\
\text { the State does } \\
\text { not refund the } \\
\text { losses, but } \\
\text { allocates } \\
\text { easy-terms } \\
\text { loans }\end{array}$ & 18 & 30 & 90 & -- \\
\hline Greece & All, except Av-Dr & $\begin{array}{l}\text { Optional } \\
\text { extension of fire } \\
\text { insurance } \\
\text { contracts. There } \\
\text { is a project to } \\
\text { introduce a } \\
\text { compulsory } \\
\text { insurance against } \\
\text { natural hazards }\end{array}$ & $\begin{array}{c}\text { Risk-based } \\
\text { (Flood and } \\
\text { Storm) }\end{array}$ & $\begin{array}{c}\text { Deductible min } \\
10 \% \text { loss }(€ 500) \\
(\mathrm{F}, \mathrm{St}) \text { and } 2 \% \\
\text { of the insured } \\
\text { value }(\mathrm{Eq})\end{array}$ & $\begin{array}{c}\text { Ex-post disaster } \\
\text { relief }\end{array}$ & 5 & 5 & 5 & -- \\
\hline
\end{tabular}




\section{Continued}

\begin{tabular}{|c|c|c|c|c|c|c|c|c|c|}
\hline Hungary & Fl-St & $\begin{array}{l}\text { Owners pay a } \\
\text { contribution to } \\
\text { the Fund. It } \\
\text { compensates the } \\
\text { owners in case of } \\
\text { losses (Fl). Storms } \\
\text { are covered by } \\
\text { every home policy }\end{array}$ & $\begin{array}{c}\text { Based on } \\
\text { property value }\end{array}$ & $\begin{array}{l}\text { Reimbursement } \\
\text { up to insured } \\
\text { value. } \\
\text { Deductibles } \\
\text { depend on the } \\
\text { policy. The } \\
\text { mean value } \\
\text { is } 200 €(\mathrm{St})\end{array}$ & $\begin{array}{l}\text { Fund for Flood } \\
\text { and Inland Water } \\
\text { Compen-sation } \\
\text { is guaranteed by } \\
\text { the state. The } \\
\text { state has refund } \\
\text { the losses in case } \\
\text { of uninsured } \\
\text { properties (St) }\end{array}$ & -- & -- & -- & -- \\
\hline Iceland & Av-Eq-Fl-Ls-VE- & $\begin{array}{l}\text { Semi-compulsory, } \\
\text { extension of fire } \\
\text { policy }\end{array}$ & Single premium & -- & $\begin{array}{l}\text { A public-private } \\
\text { partner-ship is } \\
\text { active }\end{array}$ & -- & -- & -- & -- \\
\hline Ireland & Eq-Fl-Fr-St & $\begin{array}{l}\text { Optional. The } \\
\text { household } \\
\text { insurance } \\
\text { contracts include } \\
\text { the covering of } \\
\text { damage caused by } \\
\text { natural extreme } \\
\text { events }\end{array}$ & Risk-based & -- & $\begin{array}{l}\text { The State does } \\
\text { not pay the } \\
\text { compensation } \\
\text { for damage } \\
\text { to insurers }\end{array}$ & 90 & 90 & 90 & -- \\
\hline Liechtenstein & All & $\begin{array}{l}\text { If the building is } \\
\text { localized in a site } \\
\text { exposed to } \\
\text { natural hazards, } \\
\text { the insurance is } \\
\text { mandatory. } \\
\text { Private owners to } \\
\text { avoid pay the } \\
\text { premium should } \\
\text { demonstrate that } \\
\text { their home is not } \\
\text { subject to any peril }\end{array}$ & $\begin{array}{l}\text { The size of the } \\
\text { premium } \\
\text { is regulated by } \\
\text { the state }\end{array}$ & -- & -- & -- & -- & -- & 100 \\
\hline Luxembourg & H-Fl-St-SW & $\begin{array}{l}\text { Optional } \\
\text { extension of base } \\
\text { or multi-peril } \\
\text { properties } \\
\text { insurance } \\
\text { policies }\end{array}$ & $\begin{array}{l}\text { The policy } \\
\text { price is free and } \\
\text { risk-based }\end{array}$ & -- & None & -- & 5 & 90 & -- \\
\hline $\begin{array}{l}\text { The } \\
\text { Netherlands }\end{array}$ & $\begin{array}{c}\text { All, } \\
\text { Except Eq-VE-and } \\
\text { major river flood }\end{array}$ & $\begin{array}{l}\text { Eq and F risks } \\
\text { are not insurable. } \\
\text { Insure against } \\
\text { storm is optional } \\
\text { (extension of } \\
\text { property damage) }\end{array}$ & $\begin{array}{l}\text { The policy } \\
\text { price is free and } \\
\text { risk-based. } \\
0.15 \% \text { of the } \\
\text { insured capital }\end{array}$ & $\begin{array}{c}\text { Deductibles are } \\
2 \% \text { of insured } \\
\text { capital }(\mathrm{St})\end{array}$ & $\begin{array}{l}\text { Government } \\
\text { refunds losses } \\
\text { by the Calamities } \\
\text { Compensation Act } \\
\text { for uninsurable } \\
\text { risks. Recently } \\
\text { has been } \\
\text { discussed a new } \\
\text { flood insurance } \\
\text { system as a } \\
\text { public-private } \\
\text { partnership }\end{array}$ & -- & -- & -- & $>75$ \\
\hline Norway & $\begin{array}{c}\text { Av-Cy-Eq- } \\
\text { FF-Fl-Fr-H-Ls- St-VE }\end{array}$ & $\begin{array}{l}\text { Semi-compulsory } \\
\text { as an extension of } \\
\text { fire policies }\end{array}$ & $\begin{array}{c}\text { The policy price } \\
\text { is based } \\
\text { on a flat rate }\end{array}$ & -- & $\begin{array}{l}\text { The State does not } \\
\text { guarantee the } \\
\text { losses }\end{array}$ & -- & -- & -- & $>90$ \\
\hline Poland & $\begin{array}{c}\text { Dr-Eq-Fl- Hl-Ls-St- } \\
\text { SW }\end{array}$ & $\begin{array}{c}\text { Optional } \\
\text { (Eq-Fl-St) }\end{array}$ & $\begin{array}{c}\text { The policy price } \\
\text { is free and } \\
\text { risk-based }\end{array}$ & -- & $\begin{array}{l}\text { Public funds are } \\
\text { used to compen- } \\
\text { sate for damages } \\
\text { and mitigate the } \\
\text { risks (Eq-Fl-St) }\end{array}$ & -- & 50 & 90 & -- \\
\hline
\end{tabular}




\section{Continued}

\begin{tabular}{|c|c|c|c|c|c|c|c|c|c|}
\hline Portugal & $\begin{array}{c}\text { Cy-Eq-FF-Fl-Ls- } \\
\text { Ss-St-VE }\end{array}$ & $\begin{array}{l}\text { Optional. St and } \\
\text { F coverage are } \\
\text { included in basic } \\
\text { policy. Earthquake } \\
\text { insurance is } \\
\text { offered as an } \\
\text { extension } \\
\text { of fire policy }\end{array}$ & $\begin{array}{l}\text { The policy price } \\
\text { is free } \\
\text { and risk-based }\end{array}$ & $\begin{array}{l}\text { Deductibles } 10 \% \\
\text { of damage } \\
\text { (F, St). } \\
\text { Not uniform } \\
\text { deductibles }(\mathrm{Eq})\end{array}$ & None & 5 & 50 & 50 & -- \\
\hline Romania & Eq-Fl-Ls & $\begin{array}{l}\text { Compulsory } \\
\text { insurance } \\
\text { scheme (PRAC) } \\
\text { is operative }\end{array}$ & $\begin{array}{c}\text { Fixed, depending } \\
\text { on the typology } \\
\text { of the houses } \\
\text { Type } A=20 € \\
\text { Type } B=10 €\end{array}$ & $\begin{array}{l}\text { Type A dwelling } \\
\text { (reinforced } \\
\text { concrete) }= \\
20,000 € \\
\text { Type B (walls } \\
\text { made of adobe) } \\
=10,000 € \\
\text { (for } \mathrm{F} \text { and } \mathrm{Eq} \text { ) }\end{array}$ & $\begin{array}{l}\text { A public-private } \\
\text { partner-ship is } \\
\text { active. The State } \\
\text { guarantees the } \\
\text { losses and } \\
\text { intervenes in case } \\
\text { of extraordinary } \\
\text { losses }\end{array}$ & 5 & 50 & 5 & -- \\
\hline Slovakia & Fl-St & $\begin{array}{c}\text { No } \\
\text { compulsory } \\
\text { scheme }\end{array}$ & -- & $\begin{array}{l}\text { Variable } \\
\text { limits }(F)\end{array}$ & $\begin{array}{l}\text { Public funds } \\
\text { were used in the } \\
\text { past to } \\
\text { compensate } \\
\text { the losses } \\
\text { caused by strong } \\
\text { extreme events }\end{array}$ & -- & -- & -- & -- \\
\hline Slovenia & $\begin{array}{c}\text { Av-Eq-Fi-Fl-Fr- } \\
\text { H-Ls-St }\end{array}$ & $\begin{array}{c}\text { Optional } \\
\text { Flood risk is } \\
\text { insured in most } \\
\text { household } \\
\text { content policies. } \\
\text { Coverage against } \\
\text { St/Eq is possible } \\
\text { as additional } \\
\text { coverage of } \\
\text { the buildings }\end{array}$ & $\begin{array}{l}\text { Fixed, } \\
\text { depending } \\
\text { on the } \\
\text { typology of } \\
\text { the houses } \\
(\mathrm{Eq}, \mathrm{Fl})\end{array}$ & -- & $\begin{array}{c}\text { The } \\
\text { Government } \\
\text { intervenes } \\
\text { in case of } \\
\text { extraordinary } \\
\text { losses }(\mathrm{Eq}, \mathrm{Fl})\end{array}$ & 50 & 50 & 90 & -- \\
\hline Spain & $\begin{array}{l}\text { Eq-Fl-Mt St- } \\
\text { Tn-Ts- VE }\end{array}$ & $\begin{array}{c}\text { Semi-compulsory } \\
\text { extension } \\
\text { of basic policies }\end{array}$ & $\begin{array}{l}\text { The policy price } \\
\text { is calculated on } \\
\text { a flat rates } \\
\text { fixed by the } \\
\text { State and } \\
\text { depending on } \\
\text { typology of } \\
\text { estates. } \\
\text { Houses = } \\
(0.008 \% \text { of the } \\
\text { capital insured) } \\
\text { (Eq, F, St) }\end{array}$ & $\begin{array}{c}\text { Deductibles are } \\
\text { not applied to } \\
\text { condominium and } \\
\text { dwellings. } \\
\text { (Eq, F, St) }\end{array}$ & $\begin{array}{l}\text { Policies are issued } \\
\text { by insurance } \\
\text { company or } \\
\text { Consorcio de } \\
\text { Compensacion de } \\
\text { Suguros. The } \\
\text { policies issued by } \\
\text { companies are } \\
\text { transferred to the } \\
\text { Consorcio to be } \\
\text { reinsured. The } \\
\text { State guarantees } \\
\text { all policies to be } \\
\text { reassured in case } \\
\text { of limited } \\
\text { financial capacity } \\
\text { of the Consorcio }\end{array}$ & 90 & 50 & 50 & -- \\
\hline Sweden & All & Optional insurance & $\begin{array}{l}\text { The policy } \\
\text { price is } \\
\text { calculated on } \\
\text { a flat rates } \\
\text { (Eq-Fl-St) }\end{array}$ & $\begin{array}{l}\text { Limits equal to } \\
\text { about } 525,000 € \\
\text { (as for 2010) } \\
\text { (Eq) }\end{array}$ & None & 90 & 90 & 90 & -- \\
\hline Switzerland & Av-Fl-H-Ls-St-SW & $\begin{array}{l}\text { Two different } \\
\text { systems. } \\
1 \text { 1) } \\
\text { Semi-compulsory } \\
\text { as an extension } \\
\text { of fire policies; } \\
\text { 2) compulsory }\end{array}$ & $\begin{array}{c}\text { The policy price } \\
\text { is calculated } \\
\text { on a flat rates }\end{array}$ & 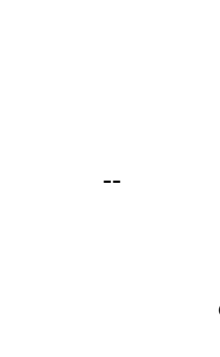 & $\begin{array}{c}\text { Intercantonal } \\
\text { Reinsu-rance } \\
\text { covers housings } \\
\text { in most of cantons } \\
\text { (19 of } 26) \text {. } \\
\text { In } 7 \text { cantons the } \\
\text { private market } \\
\text { of insurance } \\
\text { exists. The State } \\
\text { does not guarantee } \\
\text { the losses }\end{array}$ & -- & -- & -- & $>97$ \\
\hline
\end{tabular}




\begin{tabular}{|c|c|c|c|c|c|c|c|c|c|}
\hline Turkey & $\mathrm{Eq}$ & Compulsory & $\begin{array}{c}\text { Premiums } \\
\text { depends on } \\
\text { hazard zone, } \\
\text { local geological } \\
\text { features, building } \\
\text { type, extension } \\
\text { of dwelling and } \\
\text { range from } 0.04 \\
\text { to } 0.50 \% \text { of the } \\
\text { insured value }\end{array}$ & -- & $\begin{array}{l}\text { A public-private } \\
\text { partner-ship is } \\
\text { active. The State } \\
\text { does not guarantee } \\
\text { the losses }\end{array}$ & $19.6 \%$ & -- & -- & -- \\
\hline $\begin{array}{l}\text { United } \\
\text { Kingdom }\end{array}$ & $\begin{array}{c}\text { All, except } \\
\text { Av-Dh-FF-VE }\end{array}$ & $\begin{array}{l}\text { Coverage is } \\
\text { included in } \\
\text { building or home } \\
\text { contents private } \\
\text { insurance } \\
\text { (Eq-Fl-St). } \\
\text { The availability } \\
\text { of universal flood } \\
\text { insurance started } \\
\text { after UK } 2000 \\
\text { floods }\end{array}$ & $\begin{array}{l}\text { Risk based } \\
\quad(\mathrm{Fl}-\mathrm{St})\end{array}$ & $\begin{array}{c}\text { Deductibles } \\
\text { depend on } \\
\text { the policy } \\
(\mathrm{F}, \mathrm{St})\end{array}$ & $\begin{array}{l}\text { A public-private } \\
\text { partner-ship is } \\
\text { active }(\mathrm{Fl}) \text {. The } \\
\text { state does not } \\
\text { supply } \\
\text { compensation } \\
\text { of the losses and } \\
\text { reinsurance }\end{array}$ & 90 & 90 & 90 & -- \\
\hline
\end{tabular}

In Italy as well as in other countries the low penetration rate can be explained in various ways. We would emphasize on the following: inadequate risk awareness, perception that natural hazards are events of low frequency, state relief or ex-post compensation taken for granted by the population, high insurance premiums, inexistence of legislation that would make insurance mandatory, lack of energies from private insurance market to promote the need for insurance in fear unexpected catastrophic losses [22]-[25]. All the above explain the low insurance penetration rate in Italy, but in the paragraphs to follow we would mostly focus on the wrong perception people have about natural hazards and the granted state aids.

\subsection{Risk Perception}

Risk perception entails the subjective assessment of the chance of a definite peril and how concerned the persons are with the effects. It influences people to take proper actions when dealing with natural hazards, including their decision in respect of buying insurance coverage. For instance, people who perceive a risk as "high" where they live are more likely to take suitable countermeasures, adapt strategies and sustain proper institution actions even if this requires new efforts [33] [34].

Since the 60's, the research about the risk perception has led to the development of several theories such as the psychometric paradigm, that uses psychological scaling and factor analysis to obtain representations of risk perception [35], the cultural risk theory that pays attention to the importance of the cultural background and the influence that social community has on the individual aspects of risk perception [36], and the social amplification of risk framework (SARF) that focuses on psychological, institutional, social and cultural processes as factors of amplification or reduction of risk assessment [37] [38]. Amplification factors are represented, for example, by scientists involved in communicating the risk, the media, the cultural groups and the hazard experience [39]. In a word, these theories are useful in helping the experts who are engaged in encouraging suitable risk behavior for the communities, highlighting that the risk perception goes beyond the single person as it involves physiological, social and cultural aspects.

Studies focusing on the Italian context show that it is necessary to increase the risk perception. Marincioni et al. (2012) [40] who examined a sample of population involved in the 2009 L'Aquila earthquake ( $\mathrm{Mw}=6.3)$ conclude that the residents of the town had a low risk perception and no awareness of the structural performance of their own buildings. Crescimbene et al. (2014) [41] looking at the psychometric and the cultural theory approaches evaluated the seismic risk perception through the analysis of about 5000 on-line tests. The research shows that most of the Italians living in areas with high seismic hazard have either a low or incorrect risk perception, thus suggesting the need for new communication strategies. Recently, Salvati et al. (2014) [42] who analyzed the hydro-geological risk perception showed that the perception Italians have for technological risks is higher than that for natural risks and they consider the seismic events to be more dangerous than the geo-hy- 
drogeological ones. Furthermore, the authors argue that earthquake have a longer lasting influence to the way people perceive risk compared to landslides and floods. The authors conclude that more actions are required to improve the population's knowledge of the hydro-geological hazards and the associated risks.

Obviously, personal experiences may influence the risk perception and also increase the chance to buy insurance against natural perils. However, once the awareness of the hazards fades, the incentives to take countermeasures are reducing [43]. Therefore, generally speaking more time has elapsed since the last hazard occurrence the lower the risk perception becomes. For example, when we consider the most recent and striking earthquakes (site intensity greater than or equal to VII-very strong or VIII-heavy on the Mercalli-Cancani-Sieberg-MCS-macroseismic scale) that shook the Southern Italy and Sicily towns, we notice that most of places were hit by seismic events dating back to a few decades or centuries ago. In particular, analyzing the data regarding the towns involved in an earthquake having a site intensity greater than or equal to VII MCS, we can see that $1.9 \%$ and $31.7 \%$ of the places were involved in events that happened up to 30 years or between 31 and 60 years ago, respectively (Figure 1(a)) and approximately $66.4 \%$ of the towns experienced the last strong earthquake between 61 and 900 years ago. Looking at the earthquakes with the higher site intensity, equal to or greater than VIII MCS (Figure 1(b)), we can see that the percentage of the towns where earthquakes occurred in the most remote past (61 - 900 years ago) increased to $~ 89 \%$. In conclusion, these data indirectly shows that many people living in Southern Italy and Sicily, one of the highest seismic hazard zones of the country, http://zonesismiche.mi.ingv.it/mappa ps_apr04/italia.html last checked 20 July 2015, had no earthquake experiences and, as a result, they cannot have direct memories of seismic events or such memories have faded, a fact that contributes to a lower risk perception.

As being stated, in order to instill confidence with natural hazards, institutions could be alive to know in detail which and how many people living in a certain site today might have a recollection of directly experienced past

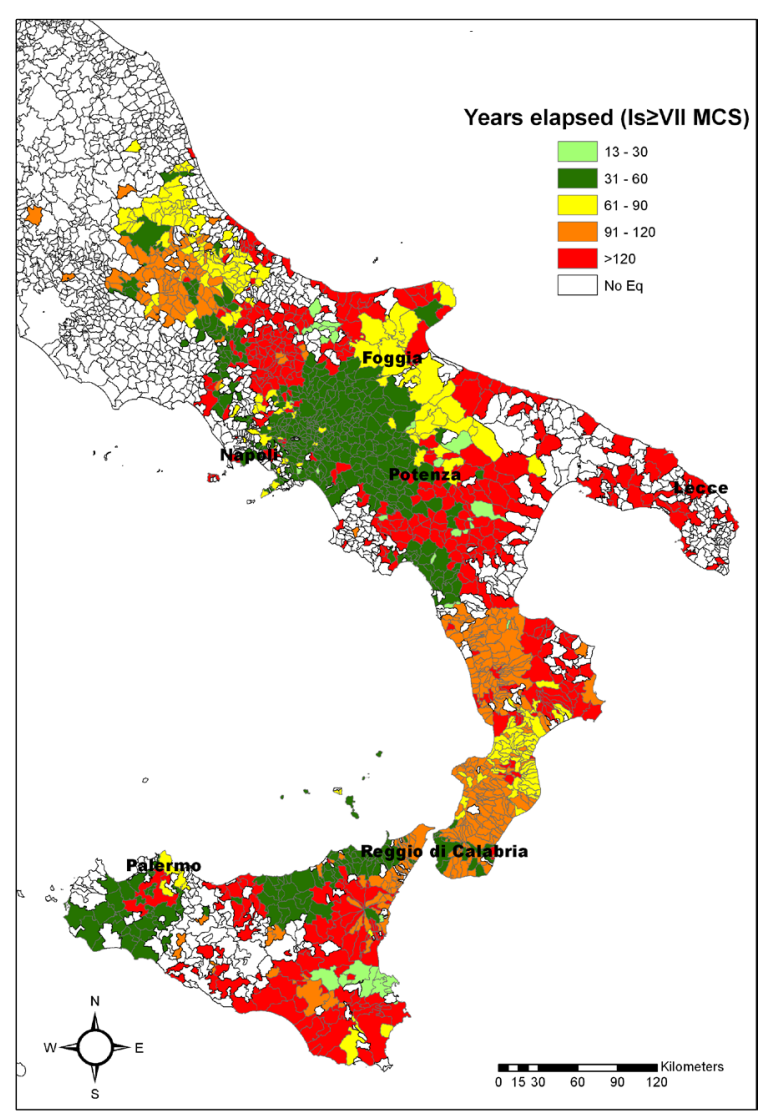

(a)

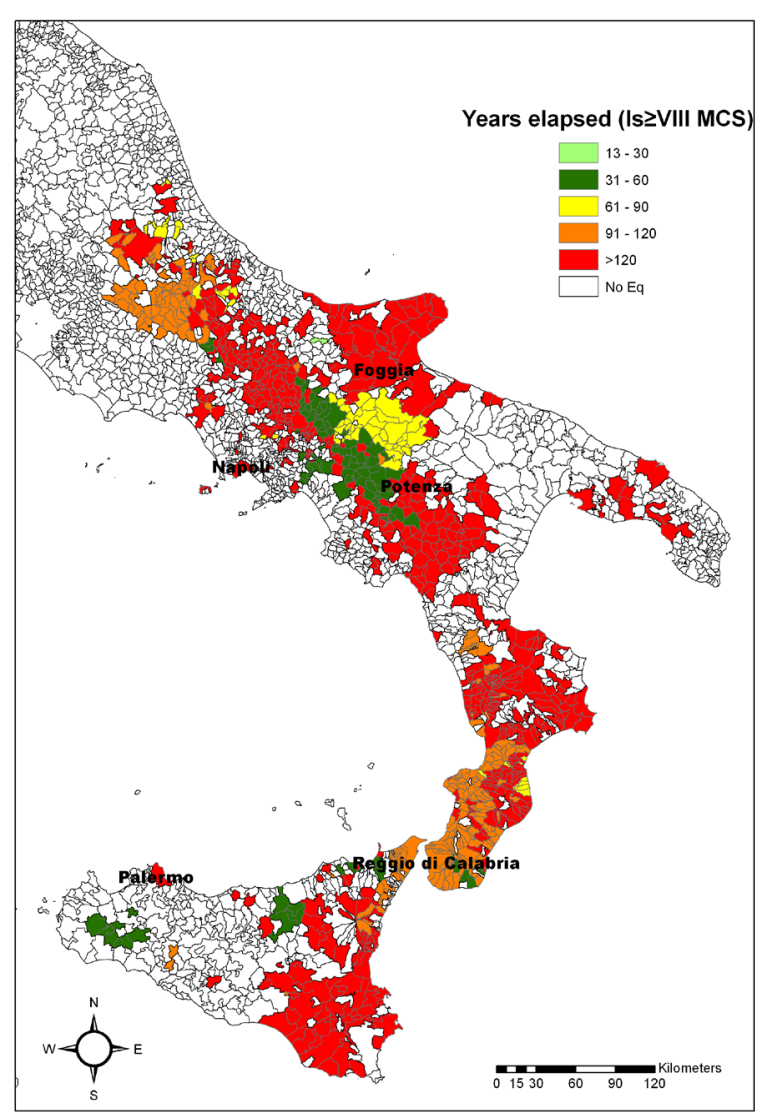

(b)

Figure 1. Years elapsed since the last earthquake that hit the towns of Southern Italy and Sicily considering the site intensity greater than or equal VII (1a) and VIII (1b) on the MCS macroseismic scale. Data on the site intensity rise from [44]. 
hazards and, at the same time, might be potentially interested in buying coverage. As a matter of fact, in order to awake the past experiences and increase the people's attitude to take mitigation and preparedness measures, including the proneness to buy insurance coverage, risk-oriented communication strategies should be addressed especially to these persons.

To identify these people we use a simplified model fixing three basic hypotheses (Figure 2). The first is the minimum age that a person should have had at the time of the earthquake occurrence to retain the memory of what he/she lived. This was assumed at 5, age from which people may start to remember the events they have lived [45]; the second concerns the minimum age that persons should have today to be able to subscribe and potentially interested in buying an insurance, which will not be less than 20 , which represents the lower age level when young people start to enter the world of work with remunerated contracts, http://www3.istat.it/salastampa/comunicati/non_calendario/20100930_00/testointegrale20100930.pdf last checked 20 July 2015; the third considers the maximum age that alive persons should have today to be interested in buying an insurance coverage, that was assumed at 70, the maximum age at which a person may be on active service in Italy today and after which the disposable personal income as well as the attention and hope in the future decrease, http://www.funzionepubblica.gov.it/TestoPDF.aspx?d=27498 last checked 20 July 2015 [46].

Bearing these three hypotheses in mind, the age classes of people (which people) living in a certain site today that might have a recall of past real-life hazards and might be interested in buying a coverage can be put in relation with the time elapsed from the recent and damaging hazard occurrence(s) ( $\Delta \mathrm{t}$ ) (Figure 2). In particular, considering the first two hypotheses discussed before, the people's ages will be between the minimum, estimated as constant and equal to 20 for $\Delta t<15$ and $(5+\Delta t)$ for $15 \leq \Delta t \leq 65$, and the maximum fixed as equal to 70 according to the third hypothesis (Figure 2, red curves, right ordinate axis).

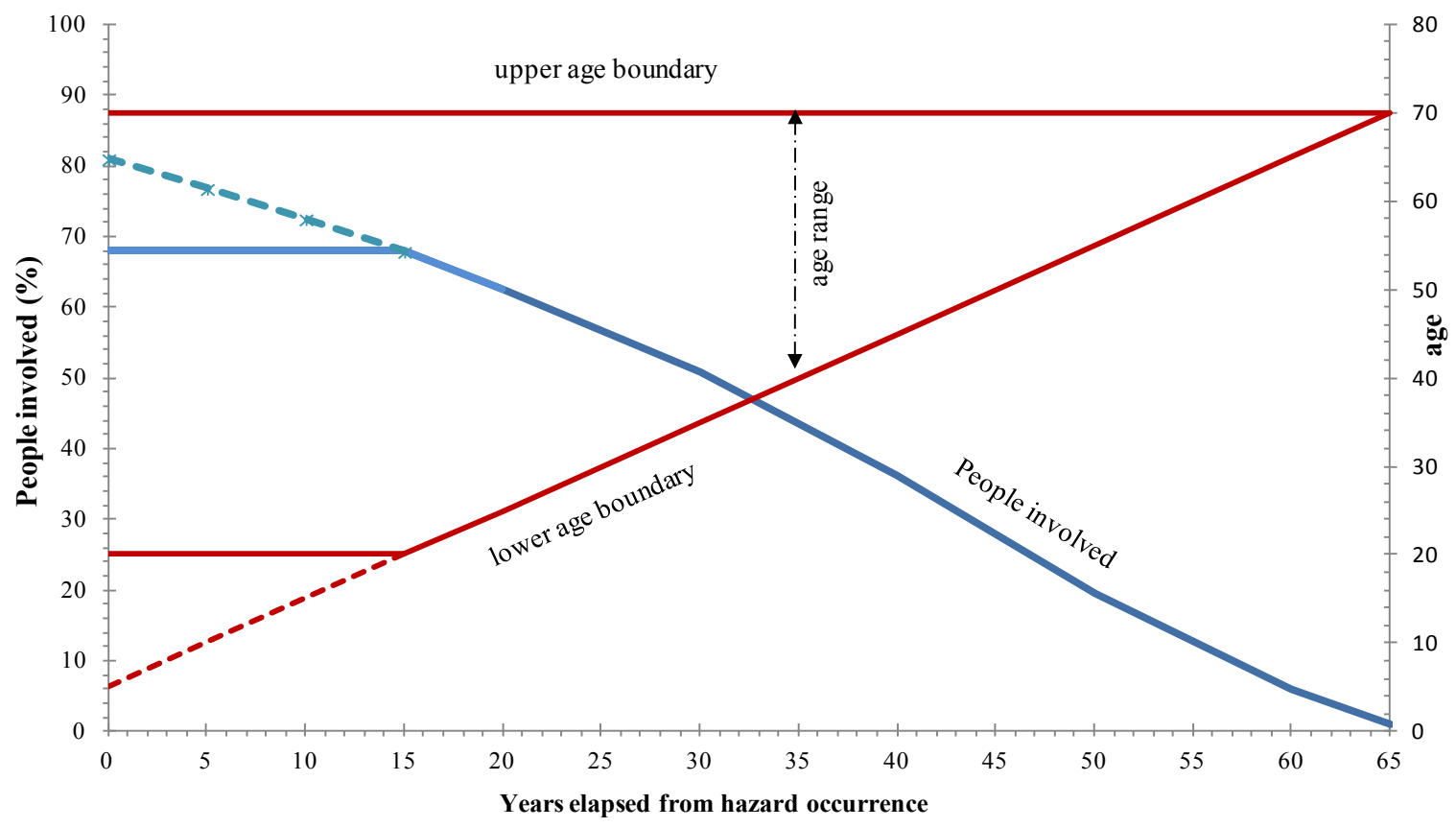

Figure 2. Graph showing which and how many people may be involved, in a certain site, in the recollection of a natural peril and that might have interest in buying coverage. General red curves (which) indicate the uppermost (70) and the lowest (5+ $\Delta t$, for $\Delta t \geq 15$ and 20 for $\Delta t<15$ ) people's age boundary (right ordinate axis) as a function of the years elapsed from the hazard occurrence. For $\Delta \mathrm{t}<15$ the age classes of people involved changes in principle (broken line), but considering that the age of people involved is under the fixed threshold of 20, the trend is assumed to be constant (continuous line). From the curves we can see that the age classes of people living in Potenza town today involved in the 1980 earthquake (occurred 35 years ago) are 40 and older. The site-specific blue curve (how many) identifies the percentage of persons (left ordinate axis) living in a certain site and having the age classes as defined by the red curves. In particular, the blue curve shows the population distribution trend for the Potenza town: 40 and older persons correspond to about $40 \%$ of the population living today. Data on Potenza population are drawn by the Italian census (URL, last checked 24 July 2015, http://www.tuttitalia.it/basilicata/71-potenza/statistiche/popolazione-eta-sesso-stato-civile-2015/). 
Regarding how many people might be involved, we consider the population census looking at the number of people living today in the site under consideration and belonging to the age levels included between the above-mentioned lowest and the uppermost age limits (Figure 2, blue curve, left ordinate axis).

To explain this better, we can take advantage of a case study regarding the high seismic hazard site of Potenza, the chief-town of the Basilicata Region, in Southern Italy (Figure 2).

Potenza is a town of about 67,000 inhabitants that throughout its history has suffered several strong earthquakes [47] of which the two most recent had a macroseismic site intensity equal to or beyond the building damage threshold (therefore potentially remained engraved on the people's memory). They occurred on 23 November 1980 (VII MCS) and 26 May 1991 (VI-VII MCS) [44].

Considering the oldest earthquake occurred, the persons living today that might be involved in the recollection and be potentially more interested than others in buying coverage can be estimated through the general red curves in Figure 2 (which), that represents the age levels involved as a general function of the time elapsed from the hazard occurrence: considering that the earthquake happened 35 years ago, the people involved today might be 40 and older. Looking at the site-specific blue curve (how many), considering that the census-based percentage of the people living in Potenza today and falling in the age ranges as defined through the red curves, we can see that the age level of 40 and older persons is equal to about $40 \%(\sim 27,000)$ of the current population. Considering the earthquake in 1991, the people involved today might be 29 and older equal to about $57 \%(\sim 38,000)$ of the actual population (a portion of which experienced also the earthquake happened eleven years before). Especially these people might be preferably addressed a risk communication campaign aimed at increasing people's confidence with risk perception and natural hazard coverage. However, in order to increase people's peril perception, the government might also, in addition to information campaigns having the well-fixed people target, enact rules regarding general hazard disclosure [43]. For example, those interested in selling and managing residential properties, such as house sale agents and apartment house managers, might be requested to inform the buyers and homeowners on the seismic hazard of the site where the real estate is located, taking advantage of official documents and maps. All that might increase the people's confidence with mitigation risk countermeasures, including insurance against unexpected losses.

\subsection{The Role of the Italian State after Past Disasters and the Growth of the Mutual Culture of Aid and Disaster Relief}

Another significant cause that can be called into the question to explain the low penetration rate regards the role that the Italian state has had in relieving the citizens from losses over the time.

Firstly, it should be noticed that the government role in disaster relief may find its ideological roots in the solidarity and subsidiary principles from which the policy of the states of catholic culture, and especially Italy, take inspiration. On the one hand, solidarity considers the mutual care and respect between human beings indispensable; on the other hand, subsidiary can be seen as a guide to set up proper social actions [48]. These principles are already present in an embryonic form starting from the Late Middle Ages and have been systematically analyzed and developed since the late XIX century in the Church Social Doctrine [49]. The Treaty of Lisbon (the document that emended the two main treaties that founded the European Community) refers to these principles. It inserts a solidarity clause (on which the Solidarity Fund is based on) among the European Members in case of special events such as natural or man-made disasters [50]. Also the Italian Constitution (1948) cites, in article 2, that: "La Repubblica riconosce e garantisce i diritti inviolabili dell' uomo, sia come singolo sia nelle formazioni sociali ove si svolge la sua personalità, e richiede l'adempimento dei doveri inderogabili di solidarietà politica, economica e sociale" (The Republic recognizes and guarantees the inviolable rights of man, as an individual, and in the social groups in which [he] expresses [his] personality, and demands the fulfillment of the unalterable duties of political, economic, and social solidarity,

http://www.constitutionnet.org/files/Italy.Constitution.pdf last checked 10 August 2015, thus identifying the solidarity principle as an important value to be taken as a reference point, even if the solidarity-inspired laws providing for the State to sustain people affected by disasters are not in force.

As being stated, in order to have a clearer picture of the role that the state has played in helping people and evaluating to what extent the state action can have influenced the citizens' behavior in copying with disasters, we will provide an overview of the main acts put into practice by the Italian governments throughout the XX century to relieve the population, paying particular attention to the seismic events, the natural peril that the Italians perceive more. 
As introduced, it is worth highlighting that due to the lack of an ex-ante public disaster funds, such as those in force in Austria and Denmark to restore private real estate, the Italian government enacts ad hoc rules to sustain the rebuilding just in the aftermath and over the years/decades following a disaster so as to compensate for the losses through the state current resources or the tax-derived ones [9].

Actually, the intervention of the State after disasters finds its embryo in the actions put into field by the ancient states Italy was made of before its Unity (1861). As a matter of fact, through tax exemptions, tax reliefs, economic incentives (e.g. 1781 Romagna earthquake), fund-raising and distribution to poor people (e.g. 1851 and 1857 Basilicata earthquakes) the policy adopted by the ancient states managed to restore the real estate roughly, thus relieving the citizens from the hard post-disaster conditions. However, the action of the ancient states did not aim to extensive deeds in the areas affected by extreme events but was unsystematic, lacking in a planning and limited as regards the economic resources put at the community's disposal, with some exceptions such as the 1693 Sicily and the 1783 Calabria huge earthquakes, after which either the wide areas of Reggio Calabria and Messina were rebuilt or the population was moved to other places [47] [51].

From the beginning of the XX century the state started actions aimed at considering extreme events as an opportunity and a catalytic effect to free the people affected from atavistic living poverty, building and urban decay, and geographic isolation. To achieve these aims the state has invested huge economic resources [52].

The role played by the state in coping with calamities can be highlighted, for example, from the analysis of the digital historical archive (1861-2013) of the Italian Chamber of Deputies, one of the two branches of the Parliament, that shows about 7000 documents searched by the word "terremoto" (earthquake), the disaster that has caused the most casualties throughout the centuries, http://storia.camera.it/ last checked 10 December 2014. Most of such results regard initiatives of the entire Chamber or single delegates to promote an economic obligation of the state in order to rebuild the public and private real-estate renew the economic activities of the areas affected and mitigate the discomforts caused to the people by the seismic events.

To examine the question from a close-up it emerges that the Messina-Reggio Calabria ravaging earthquake in 1908 represents a turn-point in the ratio of the laws enacted by the state to cope with the consequences of extreme natural events. So, after the earthquake in 1908 numerous laws were issued to finance the reconstruction of the areas damaged. The legislator focused the attention on four main points: the taxation of personal property and real estate to be transferred to the areas affected, tax exemption for real estate, grants and easy-term loans to give to the owners to carry out restoration, construction or the rebuilding of the housings damaged, a wide plan of construction through the drawing up of a town-planning scheme to be funded with easy-term loans, and tax relief to promote the development of industrial poles. To make the rebuilding faster, the grants were increased over the decades following the earthquake (e.g. Law n. 531 issued on 29 July 1949 regarding the increase of state subsidies to rebuild housings destroyed or damaged by earthquakes occurred between 1908 and 1936), testifying the government difficulties to recover the massive losses in a short time. In fact, the circumstance that one century after the earthquake about 12,000 people were still alive in the hovels built in the aftermath testifies that the ex-post interventions put into the field by the state have not been sufficient to relief the community from the huge disaster, http://www.messinacittanegata.it/interroga.htm last checked on 10 October 2014.

The principles inspiring the laws enacted after the earthquake in 1915 were quite similar to those that guided the choice made after the seismic event in 1908, but more attention was paid to the need to supply grants, and easy-term loans for the recovery of the urban, rural and industrial buildings. In order to make the economic recovery easier, more efficient measures were perfected to boost the birth of industrial plants and rural initiatives. Furthermore, the drawing up of the town-planning schemes was made easier and extended to many other towns so as to stimulate the building activities that had already taken advantage of the house subsidies put at the community's disposal by the government [15] [53].

After the Irpinia earthquake on 23 July 1930, that hit the inland towns of the Southern Apennines, the Government focused its attention both on wide reconstruction schemes and the urban growth of the sites more affected by the event. The State's policy aimed at putting at the community's disposal: emergency housings, that is to say masonry housings to be built in a short time so as to avoid, on the one hand, temporary houses such as sheds that had already proved to be an unsuitable solution after the Messina earthquake in 1908, on the other hand areas close to the urban centers where to reconstruct the damaged buildings, with the aim of creating new quarters [54]-[56].

The Irpinia earthquake on 21 August 1962 saw the issuing of laws whose principles were in line with those inspiring the laws promulgated after the earthquakes happened in the previous decades. Indeed, the government 
invested money in the public and private building allocating great resources for the schemes aimed at financing the repair, rebuilding and building of private and public housings. Moreover, the Italian RAI-TV state television started a fund-raising to help the rebuilding on the towns affected. In spite of the significant economic support to the areas hit, the rebuilding has yet to see the end [57].

After the massive Friuli earthquake in 1976 numerous laws were issued. Most of them financed the rebuilding with the aim of improving the economic growth of the area affected by boosting the industrial and agricultural production to increase the employment. According to what was made after the 1962 earthquake, all the houses were admitted to the contributions, both the first and the other houses belonging to the same owner [15].

In consequences of the devastating earthquake on 23 November 1980 the State invested very huge economic resources in facilities, building reconstruction, industrial activity and university education. The direction that the lawmaker gave the intervention on the territory was that the rebuilding of the towns had to proceed at the same rate as the economic growth [58]. To do this, the main law enacted after the disaster, the Lawn. 219 issued on 14 May 1981 regarding "Ulteriori interventi in favore delle popolazioni colpite dagli eventi sismici del novembre 1980 e del febbraio 1981. Provvedimenti organici per la ricostruzione e lo sviluppo dei territori colpiti" (Further interventions for people hit by seismic events happened on November 1980 and February 1981. Systematic rules for the reconstruction and development of the areas affected), allocated economic resources in order to: 1) adopt wide development schemes for the towns affected; 2) carried out industrialization schemes and industrial development; 3 ) guaranteed a system of grants to subsidy the rebuilding and the repairing of the housings also taking into account the need of strengthening interventions on the buildings. Also in this case, all the houses were admitted to be subsidized. About thirty laws aiming at financing or refinancing the state aids were issued from 1981 up to 2007, with an amount of investments of about 33 billion 2007/EUR that, however, they have not considered as exhaustive of the total capital appropriation by Italian State [59].

More recently, on 6 April 2009 the earthquake of magnitude $6.2(\mathrm{Mw})$ struck the Abruzzo region bringing about 309 deaths, damage to 35,000 private and 1000 public buildings in the town of L'Aquila and the surrounding areas [60]. The public economic resources allocated amount to about EUR 10.5 2007/billion, of which $73 \%$ directed to interventions on public and private buildings through the concession of subsidies. The public funds also include the European Union Solidarity Fund [61] of about EUR 500 million that have been put at the community's disposal by the EU mainly to draw up two schemes of house building (Progetto C.A.S.E. and Progetto M.A.P.). Italy has also benefited from the Fund for other five disasters, the latest was the Emilia-Romagna earthquake in May 2012 in consequence of which the biggest amount of aid (670 million $€$ ) was mobilized since the creation of the Fund itself. In addition to the earmarking of public funds, grants were given by foreign states, private citizens or associations [61] [62].

From this overview it emerges that the state and the donors perform a significant and surety role in relieving the citizens affected by the disasters. This has contributed to develop the individuals' tendency not to insure or take any other mitigation measures, highlighting a problem known in literature as charity hazard or forgiveness money [24] [63].

Summarily, public or individual helps after disasters occurred in Italy over the time might have contributed to give rise to the misconstruction or expectation, not ratified by any Italian law or regulation, that the State has an a priori obligation to rebuild the private real estate after a disaster, in accordance with a broader sense of the mutual approach to sustain the losses. The citizens' hope to receive grants, compensation and low-cost loans from local and central institutions after a disaster has rarely been questioned by the whole political class, worried about losing popularity or drawn on the temptation of significant political reward for ad hoc and ex-post compensations [64]. This can be especially true for public interventions in Southern Italy (where the penetration rate is the lowest of Italy) for which, despite the huge expenses, the economic and social questions and the development gap with the North of Italy has never been solved by the institutions [52]. In this context, any of these ex-post aids can be viewed by people as being "the right chance" to solve the atavist question and politicians could benefit from such community's hope. All that can have contributed to discourage the request for insurance cover and, consequently, chock down the debate on this issue.

\section{The Italian Insurance Market of Natural Hazards}

The need for a system that guarantees the loss cover caused by disasters has led to the drawing up of some insurance schemes throughout the EU Members. The schemes can provide a private market solution such as in 
Germany, Ireland or Italy or a close public-private partnership such as in Spain, Belgium and France (Table 1). The Italian market, however, it still hasn't been explored so far and no studies dealing with detailed information about it are available in literature. Therefore, the authors performed a research aimed at casting light upon the private insurance market of geophysical and hydrological hazards having the residential coverage in mind.

\subsection{Methodology}

Before starting the study it was necessary to have an overview of the complex Italian insurance system. This is divided into 33 groups, each of them is composed of the leader (an insurance or reinsurance enterprise or a company of insurance holding), the insurance branch enterprises and the instrumental company controlled by the group-leader. The groups are organized in 1225 insurance companies. Most of them ( 80\%) acts in the damage or damage and life insurance branch. The companies that have registered offices in Italy and are allowed to practice the activity in the Fire and Natural Elements branch are 645 (IVASS, http://www.ivass.it last checked 2 September 2013). Among these, fourteen offer insurance policies against geophysical and geo-hydrological perils, providing twenty commercial products for housings and/or condominiums.

There are seven insurance groups involved in the market, with a clear predominance of two groups (Generali and Unipol) in terms of both number of companies and commercial products put at the community's disposal.

Once selected the companies' active in supplying insurance, we analyzed in depth the pamphlets of each policy available on the market (see Reference Section and Table 2). Some additional information was gained through the policy contracts requested by the authors.

All that stated, also depending on the questions raised by official documents such as the Green Paper on the insurance of natural and man-made disasters [65], the data included in the policy documents allowed to pay attention to eight main issues: 1) insurable (and uninsurable) perils; 2) typology of policy (basic or extended); 3) type and form of policy; 4) features of the buildings insurable and uninsurable; 5) payouts; 6) indemnity limits; 7) deductibles and their amount ; 8) premiums to be paid (Table 2).

\subsection{Policy Features: State of Play}

Firstly, it should be emphasized that according to the 1912 article of the Italian Civil Code entitled Terremoto, guerra, insurrezione, tumulti popolari, the insurance companies are not obliged to compensate for the losses caused by seismic events, wars, insurrections, and social riots. Therefore, the companies that supply the natural hazard coverage act making an exception to the Code.

Seven insurance groups, through thirteen companies with registered offices in Italy, and a company with a registered office in another EU member state supply coverage of residential buildings against natural hazards (analysis of the IVASS register updated to 30 November 2012, http://www.ivass.it).

In compliance with about half of the European countries, the coverage is offered as an optional add-on of the fire insurance policies, has term after one-year and automatically expires after that period as the implicit wage settlement is not usually applied.

After these general remarks, now the coverage features are taken into consideration from close-up, according to the main eight points listed above (Table 2).

As regarding the perils insured, all the fourteen companies supply policies against the damages to properties and their content due to seismic events, while five of them propose also the "protection" for floods, which is usually bundled with the earthquake coverage to reduce the risk accumulated in the policy due to the statistical independence of the two hazards [65].

No company supplies coverage against the damage caused both by landslides, intended as a first-trigger phenomenon, and volcanic eruptions. However, secondary causes of landslide triggers, such as earthquakes or floods, are covered by many companies.

Once discussed the perils covered, it is also important to cast light upon what the companies mean by each hazard. As for the earthquake, it is defined as a sudden tremor of the earth crust due to endogenous causes and, for contractual purpose, the aftershocks recorded within 72 hours from the main shake are considered to act as a single earthquake and the resulting damage is evaluated as a "single event". Obviously, such contractual definition given by the insurers might imply non-negligible differences between the payouts and the effective damage suffered by the building as the aftershock duration might be well over the 72 hours. This contractual earthquake definition is quite different from those in force in the other European countries. For example in Belgium, where 
Table 2. Main features of the natural hazard policies in Italy. Data are drawn by the pamphlets supplemented by some estimated cost documents requested by the authors. ID = identification number of the pamphlet consulted as reported in the reference section; $\mathbf{E}=$ earthquake; $\mathbf{F}=$ Flood; $\mathbf{I}=$ Inundation; $\mathbf{R e C}=$ Replacement Cost; FL $=$ First Loss; $\mathbf{T V}=$ Total Value; TAS = Time Accident Statement, $\mathbf{H}=$ Housing; $\mathbf{C}=$ Condominium; $\mathbf{B}=$ Basic coverage; $\mathbf{E}=$ Extended coverage; $\mathbf{E R}=$ Earthquake-resistant building; $\mathbf{T}=$ traditional (reinforced concrete) building; $\mathbf{M}=$ Masonry building; $\mathbf{G B}=$ Green Building; $\mathbf{F p M}=$ Fire-proof material; $\mathbf{C h}=$ Chalet; $\mathbf{N D}=$ Not declared field; * = according to the estimated cost document. All data listed in the table are updated to August 2013. Therefore, data included here might have undergone changes.

\begin{tabular}{|c|c|c|c|c|c|c|c|}
\hline ID & Company & Insurance group & Perils covered & $\begin{array}{l}\text { Policy } \\
\text { type }\end{array}$ & $\begin{array}{c}\text { Type/form of } \\
\text { coverage } \\
\text { (tolerance) }\end{array}$ & $\begin{array}{c}\text { Assets } \\
\text { covered }\end{array}$ & $\begin{array}{c}\text { Insurable } \\
\text { building type }\end{array}$ \\
\hline 1 & Axa S.p.A. & Axa Italia & $\mathrm{E}$ & $\mathrm{B} / \mathrm{E}$ & $\mathrm{ReC} / \mathrm{TV}(20 \%)$ & $\mathrm{H}$ & ER-T-M; G.B.; Ch \\
\hline 2 & $\begin{array}{l}\text { FATA Assicurazioni } \\
\text { Danni S.p.A. }\end{array}$ & Generali & $\begin{array}{c}\mathrm{E} / \mathrm{F} / \mathrm{I} \\
\text { (bundled) }\end{array}$ & $\mathrm{E}$ & $\mathrm{ReC} / \mathrm{TV}(20 \%)$ & $\mathrm{H}$ & FpM \\
\hline 3 & $\begin{array}{l}\text { Fondiaria-Sai S.p.A. } \\
\text { (divisione SAI) }\end{array}$ & UNIPOL & E & B & $\mathrm{ReC} / \mathrm{TV}(20 \%)$ & $\mathrm{H}$ & ER-T-M* \\
\hline 4 & $\begin{array}{l}\text { Fondiaria-Sai S.p.A. } \\
\text { (divisione SAI) }\end{array}$ & UNIPOL & $\mathrm{E}$ & B & $\mathrm{ReC} / \mathrm{TV}(20 \%)$ & $\mathrm{C}$ & N.D. \\
\hline 5 & $\begin{array}{l}\text { GENERALI ITALIA } \\
\text { S.P.A. }\end{array}$ & GENERALI & E & $\mathrm{B}$ & $\mathrm{ReC} / \mathrm{TV}(20 \%)$ & $\mathrm{H}$ & FpM \\
\hline 6 & Genertel S.p.A. & Generali & $\begin{array}{c}\mathrm{E} / \mathrm{F} / \mathrm{I} \\
\text { (bundled) }\end{array}$ & B & $\mathrm{ReC} / \mathrm{FL}$ & $\mathrm{H}$ & FpM \\
\hline 7 & $\begin{array}{c}\text { Groupama } \\
\text { Assicurazioni S.p.A. }\end{array}$ & GROUPAMA & E & B & $\mathrm{ReC} / \mathrm{TV}(20 \%)$ & $\mathrm{H}$ & $\mathrm{FpM} / \mathrm{Ch} / \mathrm{GB}$ \\
\hline 8 & $\begin{array}{l}\text { Intesa Sanpaolo } \\
\text { Assicura S.p.A. }\end{array}$ & Intesa San Paolo Vita & E & B & $\mathrm{ReC} / \mathrm{FL}$ & $\mathrm{H}$ & $\begin{array}{l}\text { Building conform } \\
\text { to the anti-seismic } \\
\text { regulations }\end{array}$ \\
\hline 9 & $\begin{array}{l}\text { ITAS } \\
\text { MUTUA }\end{array}$ & ITAS ASSICURAZIONI & $\mathrm{E} / \mathrm{F} / \mathrm{I}$ & B & $\begin{array}{l}\mathrm{ReC} / \mathrm{TV}-\mathrm{FL} \\
(15 \%)\end{array}$ & & FpM \\
\hline 10 & $\begin{array}{l}\text { Llyod Italico (brand di } \\
\text { Allenza Toro S.p.A.) }\end{array}$ & Generali & E & $\mathrm{B} / \mathrm{E}$ & $\mathrm{ReC} / \mathrm{TV}(20 \%)$ & $\mathrm{H}$ & FpM \\
\hline 11 & $\begin{array}{l}\text { Llyod Italico (brand di } \\
\text { Allenza Toro S.p.A.) }\end{array}$ & Generali & $\mathrm{E} / \mathrm{F} / \mathrm{I}$ & B & $\mathrm{ReC} / \mathrm{TV}$ & $\mathrm{C}$ & FpM \\
\hline 12 & LLOYD'S & - & $\begin{array}{l}\mathrm{E} / \mathrm{F} / \mathrm{I} / \mathrm{AE} \\
\text { (bundled) }\end{array}$ & E & $\mathrm{ReC} / \mathrm{TV}(10 \%)$ & $\mathrm{H} / \mathrm{C}$ & M-T \\
\hline 13 & Milano S.p.A. & UNIPOL & E & B & $\mathrm{ReC} / \mathrm{TV}(20 \%)$ & $\mathrm{H}$ & ER-T-M ${ }^{*}$ \\
\hline 14 & Milano S.p.A. & UNIPOL & E & B & $\mathrm{ReC} / \mathrm{TV}(20 \%)$ & $\mathrm{C}$ & ND \\
\hline 15 & $\begin{array}{c}\text { Milano S.p.A. } \\
\text { (divisione SASA) }\end{array}$ & Unipol & $\mathrm{E}$ & B & $\mathrm{ReC} / \mathrm{TV}(20 \%)$ & $\mathrm{H}$ & ER-T-M \\
\hline 16 & Tua Assicurazioni S.p.A. & Cattolica Assicurazioni & E & $\mathrm{B} / \mathrm{E}$ & $\mathrm{ReC} / \mathrm{TV}(20 \%)$ & $\mathrm{H}$ & $\begin{array}{l}\text { T-M- G.B. after } \\
\text { the year } 2000\end{array}$ \\
\hline 17 & $\begin{array}{c}\text { Toro (brand di } \\
\text { Alleanza Toro S.p.A.) }\end{array}$ & GENERALI & E & $\mathrm{B} / \mathrm{E}$ & $\mathrm{ReC} / \mathrm{TV}(20 \%)$ & $\mathrm{H}$ & FpM \\
\hline 18 & $\begin{array}{c}\text { Toro (brand di Alleanza } \\
\text { Toro S.p.A.) }\end{array}$ & GENERALI & $\mathrm{E} / \mathrm{F} / \mathrm{I}$ & $\mathrm{B}$ & $\mathrm{ReC} / \mathrm{TV}(20 \%)$ & $\mathrm{C}$ & FpM \\
\hline 19 & $\begin{array}{c}\text { Unipol Assicurazioni } \\
\text { S.p.A. }\end{array}$ & UNIPOL & E & B & $\mathrm{ReC} / \mathrm{TV}(20 \%)$ & $\mathrm{H}$ & ER-T-M \\
\hline 20 & $\begin{array}{l}\text { Unipol Assicurazioni } \\
\text { S.p.A. }\end{array}$ & UNIPOL & $\mathrm{E}$ & B & $\mathrm{ReC} / \mathrm{TV}(15 \%)$ & $\mathrm{C}$ & ER-T-M \\
\hline
\end{tabular}




\begin{tabular}{|c|c|c|c|c|c|c|}
\hline ID & Uninsurable building type & TAS-(days) & $\begin{array}{c}\text { Payment } \\
\text { on } \\
\text { accont/timing }\end{array}$ & Payout timing & $\begin{array}{c}\text { Indemnity } \\
\text { limit } \\
\text { (insured value) } \\
(\%)\end{array}$ & Deductibles \\
\hline 1 & $\begin{array}{l}\text { Buildings with a structure } \\
\text { made up fully of mansonry }\end{array}$ & 7 & $\begin{array}{c}50 \% . \\
90 \text { days } \\
\text { from TAS }\end{array}$ & $\begin{array}{l}30 \text { gg. from } \\
\text { administrative } \\
\text { coverage check }\end{array}$ & $50 \%{ }^{*}$ & $\begin{array}{c}5 \% \text { of } \\
\text { insured value }\end{array}$ \\
\hline 2 & ND & 3 & $\begin{array}{l}50 \% . \\
90 \text { days }\end{array}$ & $\begin{array}{c}30 \text { gg. From } \\
\text { administrative } \\
\text { check }\end{array}$ & ND & ND \\
\hline 3 & GB & 10 & $\begin{array}{l}50 \% . \\
60 \text { days }\end{array}$ & $\begin{array}{c}30 \mathrm{gg} \text {. From } \\
\text { administrative } \\
\text { check }\end{array}$ & $50 \%$ or $70 \%{ }^{*}$ & $\begin{array}{l}5 \% \text { of insured value } \\
\text { (min. } 10,000 €) \text { or } \\
10 \% \text { (min. } 20,000 €) \\
\text { depending on } \\
\text { building type }\end{array}$ \\
\hline 4 & ND & 10 & $\begin{array}{l}50 \% \\
60 \text { days }\end{array}$ & $\begin{array}{c}30 \text { gg. From } \\
\text { administrative } \\
\text { check }\end{array}$ & ND & ND \\
\hline 5 & Building under construction & 3 & $\begin{array}{l}50 \% . \\
90 \text { days }\end{array}$ & $\begin{array}{c}30 \text { gg. From } \\
\text { administrative } \\
\text { check }\end{array}$ & ND & $\begin{array}{l}20 \% \text { of indemnity } \\
\text { (min. } 20,000 €)\end{array}$ \\
\hline 6 & $\begin{array}{c}\text { Building under } \\
\text { construction/Basements }(\mathrm{F} / \mathrm{I})\end{array}$ & 3 & $\begin{array}{l}50 \% \\
60 \text { days }\end{array}$ & - & ND & $\operatorname{Min} 7500 €(F / I)$ \\
\hline 7 & Building under construction & 5 & $\begin{array}{l}50 \% . \\
60 \text { days }\end{array}$ & $\begin{array}{c}30 \text { gg. From } \\
\text { administrative } \\
\text { check }\end{array}$ & ND & $\begin{array}{c}10 \% \text { of } \\
\text { insured value }\end{array}$ \\
\hline 8 & $\begin{array}{l}\text { Building under construction } \\
\text { or bad conservation state }\end{array}$ & 10 & $\begin{array}{l}50 \% . \\
60 \text { days }\end{array}$ & $\begin{array}{c}30 \text { gg. From } \\
\text { administrative } \\
\text { check }\end{array}$ & $50 \%$ & $\begin{array}{l}10 \% \text { of indemnity } \\
\text { (min. } 2500 €)\end{array}$ \\
\hline 9 & $\begin{array}{l}\text { Buildings in flooding area; Building } \\
\text { placed in the highest seismic } \\
\text { risk categories ( } 1 \text { or } 2) \text { according } \\
\text { to company's risk scheme }\end{array}$ & 5 & $\begin{array}{l}50 \% . \\
60 \text { days }\end{array}$ & $\begin{array}{l}30 \mathrm{gg} \text {. From the } \\
\text { liquidation act }\end{array}$ & $10.000 €$ & $\begin{array}{l}250 €(\mathrm{I} / \mathrm{A}) \\
500 €(\mathrm{E})\end{array}$ \\
\hline 10 & $\begin{array}{l}\text { Building under construction/Not } \\
\text { fitting antiseismic/urbanistic laws }\end{array}$ & 3 & $\begin{array}{l}50 \% . \\
60 \text { days }\end{array}$ & $\begin{array}{l}30 \text { gg. From the } \\
\text { liquidation act }\end{array}$ & ND & $\begin{array}{c}20 \% \text { of } \\
\text { insured value }\end{array}$ \\
\hline 11 & ND & 5 & $\begin{array}{l}50 \% . \\
90 \text { days }\end{array}$ & $\begin{array}{l}30 \text { gg. From the } \\
\text { liquidation act }\end{array}$ & $50 \%$ & $\begin{array}{l}1 \% \text { of indemnity, } \\
\text { min } 15,000 €(\mathrm{~F} / \mathrm{I}) \\
1 \% \text { of indemnity, } \\
\text { min. } 30,000 €(\mathrm{E})\end{array}$ \\
\hline 12 & ND & 8 & ND & $\begin{array}{l}30 \text { gg. From the } \\
\text { liquidation act }\end{array}$ & Insured value ${ }^{*}$ & $\begin{array}{l}\text { Min } 10,000 €- \\
\operatorname{Max} 50,000 €^{*}\end{array}$ \\
\hline 13 & Not fitting urbanistic law, $\mathrm{GB}^{*}$ & 10 & $\begin{array}{l}50 \% . \\
60 \text { days }\end{array}$ & $\begin{array}{l}30 \text { gg. From the } \\
\text { liquidation act }\end{array}$ & $50 \%$ or $70 \%$ & $\begin{array}{c}5 \%(\min .10,000)- \\
10 \%(\min .20,000) \\
\text { of insured value, } \\
\text { depending } \\
\text { on building type }\end{array}$ \\
\hline 14 & ND & 10 & $\begin{array}{l}50 \% . \\
60 \text { days }\end{array}$ & $\begin{array}{l}30 \text { gg. from the } \\
\text { liquidation act }\end{array}$ & ND & ND \\
\hline 15 & $\begin{array}{l}\text { Building under construction/Not } \\
\text { fitting antiseismic/urbanistic laws; GB }\end{array}$ & 10 & $\begin{array}{l}50 \% . \\
60 \text { days }\end{array}$ & $\begin{array}{l}30 \text { gg. from the } \\
\text { liquidation act }\end{array}$ & ND & $\begin{array}{l}5 \%(\min .10,000)- \\
10 \% \text { (min. } 20,000) \\
\text { of insured value, } \\
\text { depending on } \\
\text { building type }\end{array}$ \\
\hline 16 & $\begin{array}{l}\text { Building under construction/Not } \\
\text { fitting antiseismic/urbanistic laws }\end{array}$ & 3 & $\begin{array}{c}50 \% . \\
90 \text { days }\end{array}$ & $\begin{array}{l}30 \text { gg. from the } \\
\text { liquidation act }\end{array}$ & Insured value & $20 \%$ insured value \\
\hline 17 & $\begin{array}{l}\text { Building under construction/Not } \\
\text { fitting antiseismic/urbanistic laws }\end{array}$ & 5 & $\begin{array}{l}50 \% \\
60 \text { days }\end{array}$ & $\begin{array}{l}30 \text { gg. from the } \\
\text { liquidation act }\end{array}$ & ND & $20 \%$ insured value \\
\hline
\end{tabular}




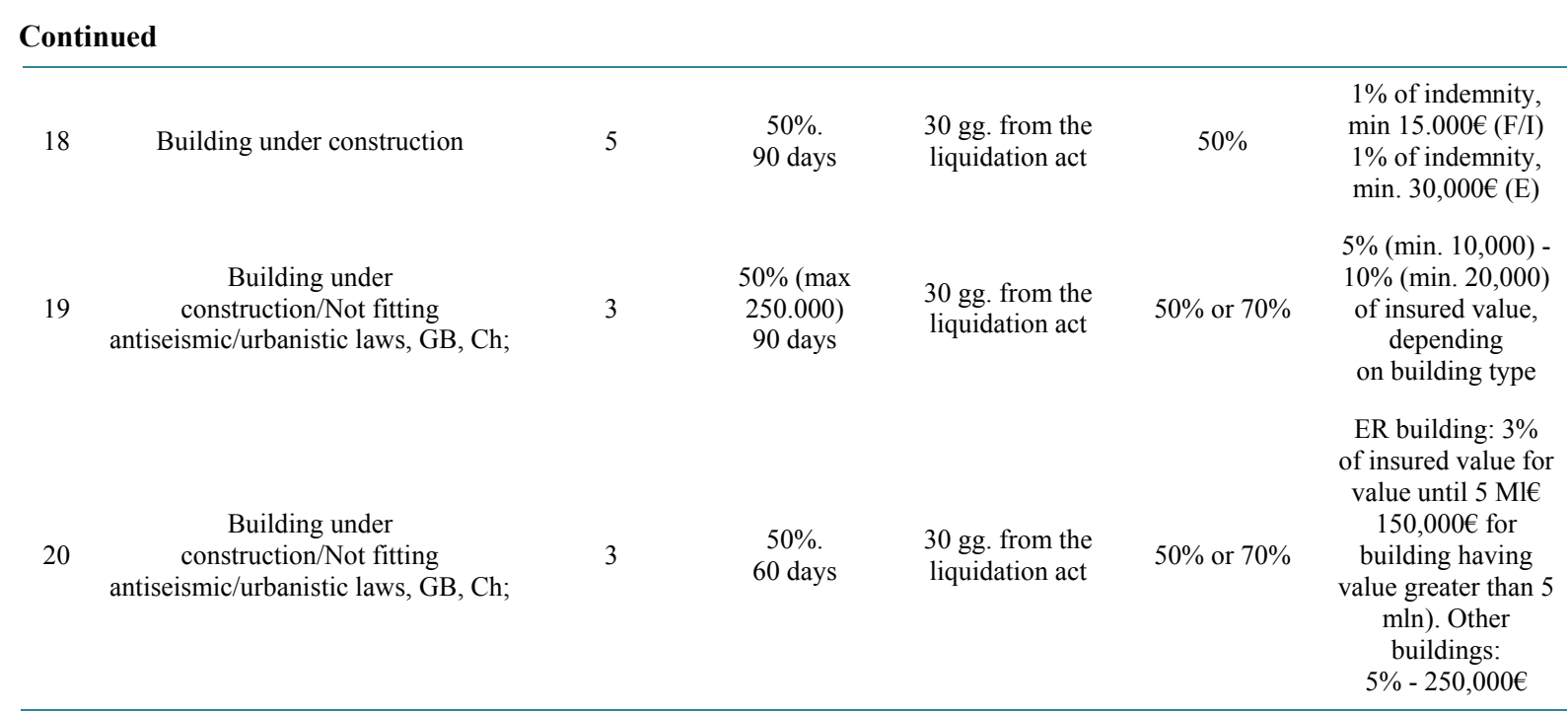

a public-private partnership is active, the cover of losses starts when a minimum magnitude of 4 is reached and the damage is recorded within a radius of $10 \mathrm{~km}$. In Germany, where a free market is in force, the definition is vaguer: the companies compensate for the losses if the earthquake causes damage in an area surrounding the site where the insured building is located and the building is in a good conservation and maintenance status [12].

Analyzing the floods, it is worth emphasizing that the definition is not always given in the informative report of the Italian insurance companies. However, most of the companies give a definition of flooding which is in a good agreement with that supplied by [66] and adopted in other European countries such as Germany and Spain: "...temporary covering of land by water as a result of surface eaters escaping from their normal confines or as a result of heavy precipitation". Only one company gives a definition that is more in accordance with the broader meaning given by the [67]: "temporary covering by water of land not normally covered by water".

As for the typology of policies, most of them $(14,70 \%)$ are basic, that is they give cover only for the rebuilding or repair costs of assets. Some coverage $(6,30 \%)$ can be underwritten with the extended option which includes the reimbursement of expenses for increased temporary living costs, the value of the house content and the income loss due to a forced interruption of the business.

As regarding the guarantee type, the value of assets insured is evaluated by all the companies through the Replacement Costs, on which the premium is estimated. So, taking into account this guarantee, the value of properties is estimated on the basis of the costs required to replace them, not depending on the market value that includes also the rate of the soil on which the building itself is founded. The Total Value is the main insurance form usually coupled with the replacement cost guarantee type. This form makes the assumption that the insured declares the whole value of the property. This means that in case the consumer fails to do so and declares a value whose difference from the real one exceeds a fixed threshold (usually $20 \%$ ); the compensation will be proportionally reduced on the basis of how much the ascertained value will be different from that declared in the contract. Therefore, the rebuilding costs and the proportional rule should be entertained adequately by the owners for them to be sure to have the right damage compensation in view of the rebuilding/repairing of the properties affected. Only three are the companies that consider the First Loss as the insurance form, that allows the customer to obtain an indemnity limits without running into indemnity reduction due to the application of the proportional rule. This form is usually made for the house content.

As regarding the residential assets covered by the policies, most of them (15) concern the houses and only few (6) policies schedule the condominium as insurable assets.

The house policy is designed for homeowners, both of detached houses and apartments in condominium. In case of dwellings the policy covers the entire residential property. On the contrary, in case of flat in a condominium the policy covers the apartment itself and the common parts of the buildings in proportion to the share of ownership of the building. As for the condominium coverage, it is addressed to the condominium administrators and it insures the whole building and each property located in it.

Taking into account the requirements that the buildings to be insured must have, a primary distinction should 
be drawn between the companies (9) that consider as necessary only the incombustibility requisite, scheduled for the "mother" fire policy, and the companies (8) that fix in detail the features that the buildings must meet. As for the latter, three are the building categories considered: earthquake-proof (in accordance with the national seismic code-O.P.C.M. 3274/2003 and successive supplements and modifications), traditional (horizontal and vertical bearing structure made up of reinforced concrete) and masonry. In the light of this, deductibles raises proportionally with the increase of the building vulnerability from the earthquake-proof category to the masonry one. The house structures that are not in accordance with technical and town-planning laws are uninsurable. Furthermore, some companies also exclude the buildings made up entirely of masonry (both load-bearing walls and vaults) typical of Italian historical centers, as well as the constructions belonging to the green building category, which are gaining ground in Italy. However, the insurance companies do not require the proof of compliance with building codes or town-planning laws, but these data are declared by the homeowner on one's own responsibility and checked by the insurance companies in the event of accident report.

Another aspect to be stressed regards the procedure to liquidate the damages, based on three steps: the report of the accident, the estimation of the damage, and the payouts. The time accident statement is required by the homeowners within a time span ranging between three and ten days. The damages can be assessed by private contracts or experts appointed by the parties, and the payments are scheduled to be liquidated within 30 days from the agreement between the parties or the administrative check of the coverage. However, the householders can obtain an advance payment on damage claim amounting to a maximum of $50 \%$ of the expected indemnity.

As for the indemnity limits, almost all the companies about which we gained relevant information fix the indemnity limits less than the amount of the rebuilding value declared in the "fire" section of the policy. These limits, fixed by the companies or chosen by the clients with a premium that changes proportionally, fluctuate between a minimum of $50 \%$ and a maximum of $70 \%$ in case of housings, and between $30 \%$ and $50 \%$ when the insured property is a condominium.

The last point that deserves to be emphasized is the application of deductibles. As for the houses, most of companies (and policies) accommodate them in an amount variable from $5 \%$ to $20 \%$ of the value insured with an amount of deductibles not less than 10,000€: very a few (4) policies link the amount of deductibles to the building typology (earthquake-proof, traditional, masonry), while the others don't regard to the building structural performance. As for condominiums, the amount of deductibles is usually fixed as a percentage of the indemnity $(1 \%)$ or as a percentage of the insured value $(3 \%)$. However, the minimum amount of deductibles fixed for earthquake policies is greater than that scheduled for flood/inundation coverage.

\subsection{Discussion of the Data}

Once listed the main features of the policies, it is necessary to discuss the possible drawbacks, also in view of a potential future start of a national insurance scheme. Therefore, particular attention will be paid to five points.

The first considers the number of policies and companies on the market. The policies are twenty and only a small percentage of companies qualified as potentially able to supply policies against natural hazards consider the offer of this guarantee advantageous or possible. Indeed, the market sees the predominance of two insurance groups such as Generali and Unipol that, totally, cover about $70 \%$ of the market. This contributes to reduce the differentiation of the supply side and, therefore, the availability of a wider range of private insurance policy options which, however, can also be due to the lack of consumers' interest. As a matter of fact, the people who ignore the hazard of the place where they live, the exposure of themselves and their own vulnerable assets and rely on the post-disaster state relief do not stimulate the companies to compete and offer a higher number of policies among which to make a choice. Therefore, the role of an aware and active consumer might stimulate the companies that at present do not supply coverage to enter the insurance market with new products and new contract options in order to meet the needs and requirements of the insured (e.g. different deductibles, indemnity limits, installments of the insurance premium). As being stated, in order to develop the insurance market the role of amplification factors useful to raise the risk perception as predicted, for example, by the SARF theory should be properly considered. Therefore, government-supported risk communication campaigns should be engaged and should regard mainly the preparedness and preventive measures that have proved to be more useful than the knowledge of the physical features of the hazard itself [34]. Furthermore, government-aided information campaigns of risk communication should also include a notice to the public about the availability of the insurance policies to protect their own assets, putting into evidence the advantages and limits of such economic tool and its 
long-established use in some European countries. The need of such a publically-funded promotion of hazard insurance purchase is necessary doubly so as companies fail to do that due to concerns about free riding from competitors [68].

The second aspect regards the perils that are covered and uncovered. The Italian insurance market supplies coverage against losses caused by hail, snow, frost, avalanches, as concerns the meteorological hazards, and floods and earthquakes as regarding the hydrological and geophysical hazards. As for the latter, it should be emphasized that the supply mainly regards policies covering earthquake damage. A few are the policies that insure properties against flood losses: about one third of the whole market is dedicated to them.

As for the perils uncovered by the market, there are the landslide and volcanic ones. As a matter of fact, Italy is one of the few EU countries together with Cyprus and Estonia (Table 1) where no policy assuring the real estate against landslides is available on the market. This is a significant limit what's more the peninsula is among the countries where this hazard is the highest as for the United Kingdom, France, and Norway where, however, the coverage is available [69]. Moreover, no company offers covering against an important geological hazard such as the volcanic one that in other EU countries, such as Spain and Norway, is covered through a compulsory extension of basic property policies (Table 1 ). One reason why the companies may not assuring such risk could be particularly relating to the problem of adverse selection [70] that is the fact that the demand for insurance might arise mainly from the large amount of the population resident in the high risk area surrounding the volcanoes, as for the Vesuvius "red zone" where $\sim 700,000$ people ( 200,000 families) live [71]. In such a context, the insurers worried about huge claims (both in number and in exposed value) by a lot of insured concentrated in this area are induced to leave out this hazard from the coverage.

The third feature to take into consideration is the criteria in determining the amount of the premium to pay and the amount of the tariff itself. Firstly, the premium price is formed considering the rebuilding value assessed on the basis of how many square meters the house (or condominium) consists of. The premium is freely determined by the market and, as hoped for by international documents [65] [72], it is based on the underlying risk as for the most of the European countries, except Norway, Spain, and Switzerland, where a flat premium is in force (Table 1). However, the insurance market weakness can influence the premium formation, as happened after two recent seismic events that hit Southern and Northern Italy. As a matter of fact, our market analysis indicates that some insurers hurt by significant damages and losses to be compensated for the 2009 L'Aquila and 2012 Emilia earthquakes, after these events took conservative criteria resulting in a temporary withdrawal of the coverage or in an increase in premiums to properties located in sites characterized by a high seismic hazard.

As above indicated, some companies consider a diversification of the premium on the basis of the building typology (vulnerability). As for the earthquakes, this can imply significant differences in terms of premium: an owner of a masonry building can pay a premium which can be twice as high as the premium paid for an earthquake-proof building, under the same other conditions. The building typology is also considered by the companies in order to fix the deductibles and impose a penalty on the buildings with a poor structural performance. On the one hand, this insurance choice represents an incentive for owners to adopt mitigation risk measurements so as to contrast the moral hazard, that is, the individual's tendency to take more risks due to the fact that they are transferred to someone else [73]; on the other hand, some problems arise to insure the house building of historical centers characterized by a high vulnerability. A compulsory covering of this property might increase the abandonment phenomenon of the minor historical centers, thus further menacing their posterity.

As regarding the amount of the premium to be paid to cover properties against losses, from a swift glance at the market through the analysis of about ten estimates requested by the authors to the companies, it shows that the premium against earthquake losses fluctuates from $0.12 \%$ to $0.32 \%$ (inclusive of tax at $22.25 \%$ and entertainment expense) of the sum insured (rebuilding value), excluding the property content. The amount of such percentages may include the coverage against flood losses that is generally bundled with the earthquake insurance. These percentages mainly depend on the hazard-site, building vulnerability, and house typology (flat in condominium or detached house). Only one company seems to supply a flat premium that is a pricing unrelated to the risk (Lloyds', www.assicurazioneterremoto.it, last checked on 14 September 2015). Even if the amount of the premium does not seem to be particularly high when compared with those in force in other countries (e.g.: Turkey, see Table 1) it may still be perceived higher because the tax load on residential Italian properties is the highest among the European countries [74]. In addition, the pre-contractual documents do not provide information on how the insurance commercial premiums are made up, especially for what concerns the amount of the "risk premium" rate [68] and the other administrative and marketing expenses. The consumers' preliminary 
knowledge of both the risk classes their home belongs to and how much the "risk premium" itself weighs up on the commercial premium might, in fact, increase the people's risk perception and the confidence in the coverage, so as to make the premium more acceptable. This aspect should be properly considered by the companies. Bearing these aspects in mind and in order to increase the request for coverage, the companies might schedule for a partial refund or a discount of the premium for those who intend to renew the policy and haven't claimed any losses within the term of the contract. This would help the consumers both to evaluate the underwriting of the contract and its renewal as favorable, thus escaping from the temptation to cancel it without claiming losses in a one-year or longer covering time span. In addition, to keep the premium lower, the insurance companies might stipulate preventive agreements with building firms to repair or rebuild the properties damaged with lower costs. In this way, the customers that instead of the damage compensation accept the restoration of the home to be made by the building contractor suggested by the companies might benefit from a lower premium and/or a deductible cut or higher compensation limits. The government might favor such agreements fixing tax relief for contractors (e.g. cut of the VAT on the building materials) entering automatically into force after the hazard occurrence.

The fourth aspect deals with the real compensation to be paid by the insurers and the time requested to compensate for the damage. The companies propose policies against earthquake losses with indemnity limits that can also be $50 \%$ in case of housings and $30 \%$ in case of condominiums. These values seem to be among the lowest in Europe. Only in Austria the limits are quite similar to those in force in the Italian market (Table 1). Furthermore, the joined application of the deductibles (among the highest in Europe), that can reach 20\% of the value insured, and the low indemnity limits may not guarantee an adequate fulfillment of the property rebuilding or repairing especially for two typologies of damaged properties: those collapsed and those slightly affected. In the first case, the compensation limit fixed by the companies will be insufficient to rebuild the housings, in the second case; the low losses won't be compensated for due to the application of deductibles. On the basis of this, a prompt simulation of the application of deductibles or indemnity limits on a large scale territory affected by a huge earthquake, such as the Irpinia one in 1980, suggests that the towns localized in the mesoseismic area are unlikely to be rebuilt only with the insurance compensation. Considering a medium-size house with a rebuilding value of $100,000 €$ and the deductibles and compensation limits as indicated above, we can see that the owners of housings affected by minor damage (e.g. $\sim 20,000 €$ ) or entirely collapsed would suffer the most significant impact of the restrictive insurance rules in terms of percentage of non-reimbursable losses. Indeed, the spread between the real economic damage and the effective insurance compensation will be high and equal to $100 \%$ of the economic damages in case of slight effects, and $50 \%$ in case of house collapse. In event of slight damage, the losses will be entirely within the deductibles, and the home owner will have to pay $20,000 €$ for repair work, in case of medium-degree damages amounting for example to $50,000 €$ the owner will have to pay the first 20,000 $€$ for repair work before coverage kick in; in case of house collapse the half of the losses $(50,000 €)$ will be non-remunerable due to the application of the indemnity limits. Therefore, the joint of premium expensive costs, the low indemnity limits and the significant level of deduction, to which the homeowners are attentive, may be an additional cause for which most of the homeowners are still reluctant to purchase insurance [30]. This may be particular relevant for the owners that have their own assets placed in low-risk areas: the customer might have no incentive in purchasing a cover as earthquake damage will rarely exceed the deductibles. Therefore, a reconsideration of the indemnity limit and deductible thresholds might meet the consumers' needs and requirements. In this connection, even if the Italian market is highly unlikely to fit the French or Spanish rules in force in a short time, some hints can be drawn from these countries where the application of compensation limits or deductibles are not scheduled. For example, a deductible system adjusted considering the risk level as made for the premium price might help the meeting between the supply and the demand, thus allowing the reduction of the adverse selection and the increase in the capital accumulation in order to cope with the consequences of future hazard impact. Another solution might consist in the companies supplying an optional surcharge for the deductible, especially for the properties located in low-risk areas. In this case, the householders who are interested in insuring the deductibles should pay an extra-premium that will guarantee for slight damage.

As regarding the time span necessary to obtain the payouts, our data show that private compensation (and consequently the property rebuilding) might be by far faster than the compensation awarded by the government so as to contribute to a decrease in the use of public funds to provide homeless people with temporary housings. The companies might emphasize this aspect adequately when informing the potential customers, also putting into evidence that the time requested for the state to give the compensation can reach several decades. The im- 
portance of coverage could be emphasized, for example, taking advantage of the past long-lasting rebuilding interventions made by the State after disasters due to insufficient grants and/or their division into installments over long or very long periods that can even reach one century or several decades (e.g. 1908 Calabria-Messina, 1962 and 1980 Irpinia earthquakes).

The fifth aspect regards the possibility of gaining (clear) information on the companies active on the market as well as the offerings by different sellers about prices, deductibles, and indemnity limits. As a matter of fact, in order to increase the customer's confidence and also compel the companies to compete in order to attract and retain new policy underwriters, clear information on features, advantages, limitations, and exclusions that is provided for by the policies should be guaranteed [43]. Despite this, from our analysis it emerges that the companies, so far, supply the customers with unclear information about the coverage, thus the consumers may find hard and discouraging to gain information about which companies and on what conditions the hazard coverage is offered. Furthermore, the insurance agency's staff were found to be inadequately skilled in the knowledge of the coverage features put at the consumer's disposal and, in some cases, they also ignored that their company offered the coverage for natural hazards.

From a general point of view, as for the pre-contractual information, each policy is accompanied by a pamphlet including information that varies rather greatly from an insurance company to another, and the head of the sections under which the information is reported lacks standardization. This rises from the fact that the three directives concerning the non-life insurances do not include specific rules to be followed by the insurance companies [65]. This implies that only a few companies include the policy information in hazard-dedicated independent section. In fact, the information regarding the coverage conditions frequently refers back to the general rules fixed for the basic (fire) coverage or directly to the policy contract (e.g. the indemnity limits, the deductibles, the type and form of coverage, the steps required to assess the damage), which the consumer could access only after asking for an estimation.

As for the content, the pamphlets do not usually include data regarding the occurrence probability of a certain hazard and the loss probability of the assets. This makes the consumers undertake efforts in the attempt of gaining such relevant knowledge, which may inhibit the policy purchase even if the consumer considers the premium cost affordable [23].

As regarding the information on the premium amount, almost all the companies require the client to go to the agency. However, once the customers have been to the agency they will be informed on the price only after the estimation approval by the company headquarter, which may require a few days. Only a company offers the consumers a web approach to obtain in a fast and easy way the estimated costs of the coverage (Lloyds', www.assicurazioneterremoto.it last checked 1 September 2014).

Bearing all that in mind, the Italian government should make up for the lack of supranational rules for non-life insurance by fixing regulations for the companies to increase people's knowledge about the hazard insurance, and make the information standard and more accessible. For example, the companies might be requested to include clear information for prospective clients in the pre-contractual documents, also taking advantage of official documents available from the Italian institutions (e.g. Civil Protection). In this perspective, the information about the effects caused by historical strong natural extreme events might be of special interest for individuals as they would be confronted with the real damage their property might incur. Furthermore, the measures and actions that individual may be engaged in to reduce the losses of future hazard events (e.g. building reinforcements and public incentives to sustain them) will contribute to make the prospective client more confident with the risk and, therefore, more willing to take suitable countermeasures.

The companies might also be required to inform the customers (e.g. homeowners and apartment house managers) about the availability, the benefits, and the costs, and all the underwriting conditions of the hazard insurance when a request for property or fire coverage is received. Similar disclosure rules might be established when a homeowner purchases the property insurance in security of a mortgage loan, as experimented in the US [43]. In addition, a company's implicit promotion action of the coverage might be that of place at the customers' disposal the coupled selling of fire and hazard insurance. The companies might choose to promote such a selling in certain peninsula areas or in specific periods of the year with the support of the government policy that should favor this option through fiscal incentives. What's more, this coupled selling might also contribute both to dispel people's attitude to believe that if the hazard coverage is sold separately from the fire coverage, the probability to encounter the effects of a disaster in their life is definitely negligible and, consequently, increase the penetration rate [75]. 
Another disclosure rule might demand and/or incentive the insurance trade associations to supply the potential customers with ICT technology-based search tools. For example, a web page (or a mobile device APP) where to perform a cross-search for insures would be able both to inform the users about the companies active in supplying coverage of private assets and make a comparison between the premiums and policy conditions. The tool might be included in the quite common web search tool that supplies a comparison between companies active in other non-life insurance branches such as that for cars. In this way, a wider group of potential customers could be reached due to little search effort made by the users as well as the circumstance that both the calamity insurance well-disposed people and those who are in the dark about the coverage could obtain fast, useful and suitable information. Lastly, the use of the web could help the companies to control the commission and administrative costs with benefits for the premium prices.

\section{Conclusions and Perspectives}

The analysis in this article shows that the Italian private insurance market has some limits on the supply side, and in fact, the insurability is not guaranteed for all hazards and properties. The premium formation presents some drawbacks, and the compensation for the insured may not be sufficient to achieve the rebuilding/repairing aims. However, some of these weak points might be reduced if the demand for insurance coverage will be greater. To make that easier, the government might conceive a set of new activities, rules, and subscription incentives within a pre-established testing time span (e.g. 3 - 5 years) at the end of which the government will evaluate the results and decide which insurance plans to put in force.

In this period one of the government's prior engagements, which also involves the insurance companies and trade associations, should be the planning of a large-scale communication programme especially addressed to well-targeted people, identified also through the approach discussed in this article, and aimed at increasing people's risk perception and their knowledge about availability and features of hazard coverage.

A rule that the state might enact is a clause excluding those who fail to purchase insurance from public aids. Simultaneously, the same rule should take account of a safeguard clause to guarantee damage compensation by the government for uninsurable hazards or low-income householders' properties.

In order to sustain both the policy-holders and the insurers, the government might provide for fiscal incentives such as a tax relief on the premiums (22.5\%) or the tax allowance of the premium with a scaling system depending on the owner income, house size and its use (e.g. main or second home). The claw back would result in a medium-term period due both to a cut in public expenditure for less damage compensation in consequence of future disaster and internal revenue due to an increase in the policy signature rate. Alternative fiscal incentives might also be scheduled in the renewal plan of the house local taxing system, aiming at reducing the tax burden on residential properties, which is being disputed by the Italian parliament in these months. A quote of such tax reduction could be reserved for those who sign an insurance policy. The town council should be assigned the authority to decide the amount of the tax cut on the basis of a scaling system depending on the risk level which affects the municipal territory.

In order to develop the market, the government rules might contemplate fiscal incentives for insurers who enter the market of natural hazards and/or disincentives for companies that fail to do so. The grant of fiscal incentives could be met once achieved the pre-fixed thresholds of new policy signatures. However, the government should also take actions to encourage the mutual risk retention by setting up insurance pools able to put aside sufficient resources to compensate for the damages adequately, so as to meet the requirement of European directives (e.g. Solvency II).

Once the testing period is expired, the government might evaluate whether the results are encouraging or completely unsatisfactory on the basis of the penetration rate. In case of persistent underinsurance, the government might establish a national scheme bearing in mind the European experiences according to which the penetration rate is among the highest in the countries where the insurance policy is based on semi-mandatory or obligatory schemes and/or the state does not compensate for damages. However, the adoption of one of these schemes would imply a leading role of the government, not only in the enactment of rules or incentives but also in acting as a public insurer or re-insurer. Under this perspective, further research should evaluate the technical feasibility, the benefits and the drawbacks of a national insurance design developed along two different lines over the Italian territory like the one which is in force in Switzerland (Table 1). As a matter of fact, the Italian regions/territories where the penetration rate will be considered adequate after the testing period should let the 
market develop freely. On the contrary, for the regions with a negligible/unsatisfactory number of new underwritten policies it might be necessary to evaluate the possibility for the State to take a monopolist role in a compulsory insurance system.

However, whatever the solution may be adopted in the future, the discussion about the approach to follow to cope with future hazard impacts is more and more necessary, as also hoped by the international institutions. The final aim is to guarantee suitable, timely and uniform levels of rebuilding after disasters considering both the pressing need imposed by the European institutions in controlling the national balance and the rise of natural disasters over the time.

\section{Acknowledgements}

The authors thank Basilicata Region for supporting this activity in the framework of the Project "PRO_CULT" (Advanced methodological approaches and technologies for Protection and Security of Cultural Heritage) financed by Regional Operational Programme ERDF 2007/2013.

\section{Pamphlets Consulted (with ID Number-from 1 to 20-as for Table 2) (In Italian)}

1-Protezione Familiare (Mod. 2126 ed. 12/2010) e Protezione Familiare per il terremoto (Mod. 2076 ed 12/2010-print 10/2012)

2-Soluzione Fata per la casa (Mod. 80/001-Ed. 07/2011)

3-Retailpiù Casa Classic (Cod. Prod. 11538 Ed. 03/2013)

4-Retail Più Fabbricati Classic (Cod. Prod. 11481 ed. 04/2013)

5-Casa Dolce Casa(Mod. 1541-Last update 01 July2013) e Protezione Sisma (Mod. 11700 last update17 March 2012)

6-Quality home (ed. 10/2012)

7-Qui Abito casa (Mod. 250064C-Ed. 01/2011 and Ed. 06/2012)

8-Polizza Abitazione \& Famiglia(Mod. 185639 Ed. 08/2013)

9-Habitas+ (Mod. X2004.0-Ed. 05/2012)

10-Formula Casa Più (Mod. S01L-480-Ed. 06/2011 e Garanzia Terremoto Casa (Mod. S01L-508 ed.11/2012)

11-Formula Immobili Più (Mod. S01L-490-Ed. 03/2011)

12-Nota Informativa Assicurazione Globale Abitazione Catastrofi Naturali (BDB-Ed. 12/2010)

13-Difesa Più Casa (Cod. Prod. 11556 ed. 03/2013)

14-Difesa Più Fabbricati Full (Cod. Prod. 11499 ed. 04/2013)

15-Nuova Casa \& Cose SASA (Mod. SA1989/c- Ed. 04/2013)

16-Tua Famiglia (Mod. FASFAM 5 Ed. 06/2012)

17-Master Casa (PB59B300.D11 - 10307845 - Reprint March 2013) e Garanzia Terremoto Casa (Ed. 11/2012)

18-Master Fabbricati Progress (PB59G200.311 - 10311683 -Reprint May 2012)

19-You casa (Mod. 7261-Ed. 10/2012)

20-You Condominio (Mod. 7260-Ed. 15/03/2013)

\section{References}

[1] Skoufias, E. (2003) Economic Crises and Natural Disasters: Coping Strategies and Policy Implications. World Development, 31, 1087-1102. http://dx.doi.org/10.1016/S0305-750X(03)00069-X

[2] Schwab, A.K., Eschelbach, K. and Brower, D.J. (2007) Hazard Mitigation and Preparedness. Wiley \& Sons, Hoboken.

[3] Xiao, Y. (2011) Local Economic Impacts of Natural Disasters. Journal of Regional Science, 51, 804-820. http://dx.doi.org/10.1111/j.1467-9787.2011.00717.x

[4] Barredo, J.I. (2007) Major Flood Disasters in Europe: 1950-2005. Natural Hazards, 42, 125-148. http://dx.doi.org/10.1007/s11069-006-9065-2

[5] Picard, P. (2008) Natural Disaster Insurance and the Equity-Efficiency Trade-Off. Journal of Risk and Insurance, 5, 17-38. http://dx.doi.org/10.1111/j.1539-6975.2007.00246.x

[6] Bouwer, L.M. (2011) Have Disaster Losses Increased due to Anthropogenic Climate Change? Bulletin of the American Meteorological Society, 92, 39-46. http://dx.doi.org/10.1175/2010BAMS3092.1

[7] Neumayer, E. and Barthel, F. (2011) Normalising Economic Loss from Natural Disasters: A Global Analysis. Global 
Environmental Change, 21, 13-24. http://dx.doi.org/10.1016/j.gloenvcha.2010.10.004

[8] OECD (Organization for Economic Cooperation and Development) (2012) Disaster Risk Assessment and Risk Financing. URL Last Checked 12 January 2014. http://www.oecd.org/gov/risk/ G20disasterriskmanagement

[9] Schwarze, R., Schwindt, W.H.H., Raschky, P., Zahn, F. and Wagner, G.G. (2011) Natural Hazard Insurance in Europe: Tailored Responses to Climate Change Are Needed. Environmental Policy and Governance, 21, 14-30. http://dx.doi.org/10.1002/eet.554

[10] Amendola, A., Ermoliev, Y. and Ermolieva, T. (2000) Earthquake Risk Management: A Case Study for an Italian Region. Proceedings of the 2 nd European Conference on Global Change and Catastrophe Risk Management, Earthquake Risks in Europe IIASA, Laxenburg, 267-295.

[11] OECD (Organization for Economic Cooperation and Development) (2008) Financial Management of Large-Scale Catastrophes. URL Last Checked 12 January 2014. http://www.oecd.org/daf/fin/insurance/financialmanagementoflarge-scalecatastrophes.htm

[12] CEA (European Insurance and Reinsurance Federation) (2011) Insurance of Natural Catastrophe in Europe. Position Paper, URL Last Checked 16 January 2014.

[13] Maccaferri, S., Cariboni, F. and Campolongo, F. (2012) Natural Catastrophes: Risk Relevance and Insurance Coverage in the EU. Technical Report, URL Last Checked 25 February 2013. http://ec.europa.eu/finance/insurance/docs/natural-catastrophes/jrc_report_on_nat_cat_en.pdf

[14] ANIA-Guy Carpenter-CONSAP (Associazione Nazionale fra le Imprese Assicuratrici-Guy Carpenter-Concessionaria Servizi Assicurativi Pubblici S.p.A.) (2011) Danni da eventi sismici e alluvionali al patrimonio abitativo italiano: studio quantitativo e possibili schemi assicurativi. (In Italian) URL Last Checked 10 February 2013. www.ania.it/export/sites/default/it/pubblicazioni/monografie-e-interventi/Danni/Danni-da-eventi-sismici-e-alluvionali. pdf

[15] Guidoboni, E., Ferrari, G., Mariotti, D., Comastri, A., Tarabusi, G. and Valensise, G. (2007) CFTI4Med, Catalogue of Strong Earthquakes in Italy (461 BC-1997) and Mediterranean Area (760 BC-1500). INGV-SGA, URL Last Checked 20 July 2015. http://storing.ingv.it/cfti4med/

[16] Baratta, M. (1901) I terremoti d'Italia. Forni (Reprint), Torino. (In Italian)

[17] Gizzi, F.T., Potenza, M.R. and Zotta, C. (2012) 23 November 1980 Irpinia-Basilicata Earthquake (Southern Italy): Towards a Full Knowledge of the Seismic Effects. Bulletin of Earthquake Engineering, 10, 1109-1131. http://dx.doi.org/10.1007/s10518-012-9353-Z

[18] Vallario, A. (2001) Il dissesto idrogeologico in Campania. CUEN s.r.l., Napoli. (In Italian)

[19] Rose, M.D. (2012) Decision Making Errors and Socio-Political Disputes over the Vajont Dam Disaster. Disaster Advances, 5, 144-152.

[20] Paronuzzi, P. and Bolla, A. (2012) The Prehistoric Vajont Rockslide: An Updated Geological Model. Geomorphology, 169, 165-191. http://dx.doi.org/10.1016/j.geomorph.2012.04.021

[21] ANIA (Associazione Nazionale fra le Imprese Assicuratrici) (2013) Italian Insurance 2012-2013. URL Last Checked 10 June 2015.

http://www.ania.it/export/sites/default/it/pubblicazioni/rapporti-annuali/Italian-Insurance-Statistical-appendix/Italian-In surance-in-2012-2013.pdf

[22] Kunreuther, H. (1996) Mitigating Disaster Losses through Insurance. Journal of Risk and Uncertainty, 12, 171-187. http://dx.doi.org/10.1007/BF00055792

[23] Kunreuther, H. and Pauly, M. (2004) Neglecting Disaster: Why Don't People Insure Against Large Losses? Journal of Risk and Uncertainty, 28, 5-21. http://dx.doi.org/10.1023/B:RISK.0000009433.25126.87

[24] Raschky, P.A. and Weck-Hannemann, H. (2007) Charity Hazard: A Real Hazard to Natural Disaster Insurance? Environmental Hazards, 7, 321-329. http://dx.doi.org/10.1016/j.envhaz.2007.09.002

[25] Schwarze, R. and Wagner, G.G. (2007) The Political Economy of Natural Disaster Insurance: Lessons from the Failure of a Proposed Compulsory Insurance Scheme in Germany. European Environment, 17, 403-415. http://dx.doi.org/10.1002/eet.456

[26] Selcuk, S., Yazici, S. and Gulkan, P. (2001) Compulsory Earthquake Insurance Scheme for Residences in Turkey and Its Financial Implications. Journal of International Insurance, 2, 447-457. http://dx.doi.org/10.1023/A:1019916008885

[27] Priest, S.J., Clarck, M.J. and Treby, E.J. (2005) Flood Insurance: The Challenge of the Uninsured. Area, 37, $295-302$. http://dx.doi.org/10.1111/j.1475-4762.2005.00633.x

[28] Botzen, W.J.W. and Van Den Bergh, J.C.J.M. (2008) Insurance against Climate Change and Flooding in the Netherlands: Present, Future and Comparison with Other Countries. Risk Analysis, 28, 413-426. http://dx.doi.org/10.1111/j.1539-6924.2008.01035.x 
[29] Url, T. and Sinabell, F. (2008) Flood Risk Exposure in Austria: Options for Bearing Risk Efficiently. Schmollers Jahrbuch (Journal of Applied Social Science Studies), 128, 593-614. http://dx.doi.org/10.3790/schm.128.4.593

[30] Naoi, M., Seko, M. and Sumita, K. (2010) Community Rating, Cross Subsidies and Underinsurance: Why So Many Households in Japan Do Not Purchase Earthquake Insurance. Journal of Real Estate Finance and Economics, 40, 544561. http://dx.doi.org/10.1007/s11146-009-9224-9

[31] Aerts, J.C.J.H. and Botzen, W.J.W. (2011) Climate Change Impacts on Pricing Long-Term Flood Insurance: A Comprehensive Study for the Netherlands. Global Environmental Change, 21, 1045-1060. http://dx.doi.org/10.1016/j.gloenvcha.2011.04.005

[32] Petseti, A. and Nektarios, M. (2012) Proposal for a National Earthquake Insurance Programme for Greece. The Geneva Papers, 37, 377-400. http://dx.doi.org/10.1057/gpp.2012.12

[33] Armaş, I. (2006) Earthquake Risk Perception in Bucharest, Romania. Risk Analysis, 26, 1223-1234. http://dx.doi.org/10.1111/j.1539-6924.2006.00810.x

[34] Plapp, T. and Werner, U. (2006) Understanding Risk Perception from Natural Hazards: Examples from Germany. In: Vullet, A.D., Ed., Risk 21 - Coping with Risks due to Natural Hazards in the 21st Century, Taylor and Francis Group, London, 101-107.

[35] Fischhoff, B., Lichtenstein, P., Read, S. and Combs, B. (1978) How Safe Is Safe Enough? A Psychometric Study of Attitudes towards Technological Risks and Benefits. Policy Sciences, 9, 127-152. http://dx.doi.org/10.1007/BF00143739

[36] Douglas, M. and Aaron, W. (1982) Risk and Culture. University of California Press, Berkeley.

[37] Pidgeon, N., Kasperson, R.E. and Slovic, P. (2003) Introduction. In: Pidgeon, N., Kasperson, R.E. and Slovic, P., Eds., The Social Amplification of Risk, Cambridge University Press, Cambridge, UK, 1-10. http://dx.doi.org/10.1017/CBO9780511550461.001

[38] Renn, O. (2011) The Social Amplification/Attenuation of Risk Framework: Application to Climate Change. Wiley Interdisciplinary Reviews: Climate Change, 2, 154-169. http://dx.doi.org/10.1002/wcc.99

[39] Kasperson, R.E., Ortwin, R., Slovic, P., Brown, H.S., Emel, J., Goble, R., Kasperson, J.X. and Ratick, S. (1988) The Social Amplification of Risk: A Conceptual Framework. Risk Analysis, 8, 177-187. http://dx.doi.org/10.1111/j.1539-6924.1988.tb01168.x

[40] Marincioni, F., Appiotti, F., Ferretti, M., Antinori, C., Melonaro, P., Pusceddu, A. and Oreficini-Rosi, R. (2012) Perception and Communication of Seismic Risk: The 6 April 2009 L'Aquila Earthquake Case Study. Earthquake Spectra, 28, 159-183. http://dx.doi.org/10.1193/1.3672928

[41] Crescimbene, M., La Longa F. and Camassi R. (2014) What's the Seismic Risk Perception in Italy? In: Lollino, G., et al., Eds., Engineering Geology for Society and Territory, Vol. 7, Springer International Publishing, Switzerland, 69-75. http://dx.doi.org/10.1007/978-3-319-09303-1_13

[42] Salvati, P., Bianchi, C., Fiorucci, F., Giostrella, P., Marchesini, I. and Guzzetti, F. (2014) Perception of Flood and Landslide Risk in Italy: A Preliminary Analysis. Natural Hazards Earth System Science Discussions, 2, 3465-3497.

[43] Palm, R. (1998) Demand for Disaster Insurance: Residential Coverage. In: Kunreuther, H. and Roth, R.J., Eds., Paying the Price: The Status and Role of Insurance Against Natural Disasters in the United States, Joseph Henry Press, Washington DC, 51-66.

[44] Locati, M., Camassi, R. and Stucchi, M. (2011) DBMI11, la versione 2011 del DataBase Macrosismico Italiano. URL Last Checked 27 April 2014. http://emidius.mi.ingv.it/DBMI11

[45] McNally, R.J. (2005) Debunking Myths about Trauma and Memory. Canadian Journal of Psychiatry, 50, 817-822.

[46] MEF (Ministero dell'Economia e delle Finanze) (2013) Tassi di sostituzione del sistema pensionistico pubblico e complementare. In: Le tendenze di medio-lungo periodo del sistema pensionistico e socio-sanitario. Previsioni elaborate con i modelli della Ragioneria Generale dello Stato aggiornati al 2013, Rapporto n. 14, 157-174. (In Italian)

[47] Gizzi, F.T. and Masini, N. (2007) Historical Earthquakes and Damage Patterns for Potenza (Basilicata, Southern Italy). Annals of Geophysics, 50, 599-611.

[48] Schweigert, F.J. (2002) Solidarity and Subsidiarity: Complementary Principles of Community Development. Journal of Social Philosophy, 33, 33-44. http://dx.doi.org/10.1111/1467-9833.00122

[49] Mirilli, M. (2006) Solidarietà e sussidiarietà nella dottrina sociale della Chiesa: implicazioni reciproche. Degree at the Accademia Alfonsiana della Pontificia Università Lateranense, Istituto Superiore di Teologia Morale, Academic Year 2005-2006. (In Italian)

[50] CEU (Council of the European Union) (2012) Consolidated Versions of the Treaty on European Union and the Treaty on the Functioning of the European Union and the Charter of Fundamental Rights of the European Union. Brussels, 6655/7/08REV 7. URL Last Checked 5 February 2013. http://register.consilium.europa.eu/ 
[51] Guidoboni, E. and Ferrari, G. (2000) The Effects of Earthquakes in Historical Cities: The Peculiarity of the Italian Case. In: Catalogue of Strong Italian Earthquakes from 461 BC to 1997, Introductory Texts Annals of Geophysics, 43, 667-686.

[52] Gizzi, F.T., Potenza, M.R. and Zotta, C. (2015) Le ricostruzioni in Irpinia ed in Basilicata dopo i terremoti del 1930, 1962 e 1980: Confronti ed implicazioni. In: Galadini, F. and Varagnoli, C., Eds., Ricostruzioni. Marsica 1915-L'Aquila 2015, in Press. (In Italian)

[53] Staiti, M.F. (1999) Normativa e legislazione a seguito del terremoto del 13 gennaio 1915. In: Castenetto, S. e Galadini, F., Eds., 13 gennaio 1915. Il terremoto nella Marsica, Agenzia di Protezione Civile, Servizio Sismico Nazionale Istituto Poligrafico e Zecca dello Stato, Roma, 497-510.

[54] Gizzi, F.T. and Masini, N. (2004) Damage Scenario of the Earthquake on 23 July 1930 in Melfi: The Contribution of the Technical Documentation. Annals of Geophysics, 47, 1641-1665.

[55] Gizzi, F.T. (2009) The Electronic Trading Site eBay as a Useful Tool for Obtaining Historical Data on Natural Events. Computers \& Geosciences, 9, 1950-1957. http://dx.doi.org/10.1016/i.cageo.2008.12.016

[56] Gizzi, F.T., Masini, N., Potenza, M.R. and Zotta, C. (2010) La risposta istituzionale all'evento: modalità, tempi ed aspetti economici. In: Gizzi, F.T. and Masini, N., Eds., Dalle Fonti all'Evento: percorsi strumenti e metodi per l'analisi del terremoto del 23 Luglio 1930 nell'area del Vulture, Edizioni Scientifiche Italiane, Napoli, 245-266. (In Italian)

[57] Gizzi, F.T. (2012) Il "Terremoto bianco" del 21 agosto 1962. Aspetti macrosismici, geologici e risposta istituzionale, Con la Collaborazione di Maria Rosaria Potenza e Cinzia Zotta, Prefazione di Sergio Castenetto. Zaccara Editore, Lagonegro, p. 736. (In Italian)

[58] Gizzi, F.T., Potenza, M.R., Sileo, M. and Zotta, C. (2015) Reconstructions, Transfers and Forced Abandonments Brought about by Earthquakes and Landslides in the Historical Centres of Southern Italy: The Role of Primary Sources. Engineering Geology for Society and Territory, 8, 453-457. http://dx.doi.org/10.1007/978-3-319-09408-3 79

[59] Corte dei Conti (2008) La gestione dei fondi per il terremoto in Irpinia e Basilicata, in relazione al rifinanziamento di cui alla legge 27 dicembre 2006, n. 296. (In Italian) URL Last Checked 5 February 2013.

http://www.corteconti.it/export/sites/portalecdc/_documenti/controllo/sez_centrale controllo_amm_stato/2008/delibera 212008 g.relazione.pdf

[60] Protezione Civile (2009) Verifiche di agibilità agli edifici danneggiati. Data Update to 3 November 2009. (In Italian) URL Last Checked 12 February 2014. http://www.protezionecivile.gov.it/ cms/attach/editor/verifiche

[61] EUSF (EU Solidarity Fund) (2013) List of All Interventions since 2002. URL Last Checked 6 February 2014. http://ec.europa.eu/regional_policy/en/funding/solidarity-fund/

[62] Ministro per la Coesione Territoriale (2012) Relazione sulla ricostruzione dei comuni del cratere aquilano. URL Last Checked 12 January 2014.

http://www.commissarioperlaricostruzione.it/Informare/Normative-e-Documenti/Documenti-del-Ministero-per-la-Coes ione-Territoriale/Linee-guida-per-la-ricostruzione-dei-comuni-del-cratere-aquilano/Dossier-informativo-La-ricostruzio ne-dei-comuni-del-cratere-aquilano

[63] Alexander, D.E. (2014) Political Responses to Emergencies. In: Collins, A.E., Jones, S., Manyena, B. and Jayawickrama, J., Eds., Hazards, Risks and Disasters in Society, Elsevier, Amsterdam, 217-231.

[64] Deporter, B. (2006) Horizontal Political Externalities: The Supply and Demand of Disaster Management. Duke Law Journal, 56, 101-125.

[65] European Commission (2013) Green Paper on the Insurance of Natural and Man-Made Disasters. URL Last Checked 20 October 2015. http://ec.europa.eu/finance/insurance/consumer/natural-catastrophes/index en.htm

[66] Kron, W. (2002) Flood Risk = Hazard $\times$ Exposure $\times$ Vulnerability. In: Wu, M., et al., Eds., Flood Defence, Science Press, New York, 82-97.

[67] CEC (Commission of the European Communities) (2006) Proposal for a Directive on the Assessment and Management of Floods. Commission of the European Communities, COM, Brussels.

[68] Clarke, D.J. and Grenham, D. (2013) Microinsurance and Natural Disasters: Challenges and Options. Environmental Science \& Policy, 27, 89-98. http://dx.doi.org/10.1016/j.envsci.2012.06.005

[69] ESPON (European Spatial Planning Observation Network) (2005) Europe: Landslide Hazard Map. URL Last Checked 16 January 2014. http://www.preventionweb.net/files/3829_LandslidehazardN3.jpg

[70] Kunreuther, H. (1998) Insurability Conditions and the Supply of Coverage. In: Kunreuther, H. and Roth, R.J., Eds., Paying the Price: The Status and Role of Insurance against Natural Disasters in the United States, Joseph Henry Press, Washington DC, 17-50.

[71] Protezione Civile (2014) Aggiornamento del Piano nazionale di emergenza per il Vesuvio. URL Last Checked 12 Sep- 
tember 2015. http://www.protezionecivile.gov.it/jcms/it/view dossier.wp?contentId=DOS37096

[72] OECD (Organization for Economic Cooperation and Development) (2012) Good Practices for Mitigating and Financing Catastrophic Risks. OECD Recommendation, URL Last Checked 12 January 2014. http://www.oecd.org/daf/fin/insurance/47170156.pdf

[73] Shavell, S. (1979) On Moral Hazard and Insurance. Quarterly Journal of Economics, 93, 541-562. http://dx.doi.org/10.2307/1884469

[74] EU.R.E.S. (Ricerche Economiche e Sociali) (2012) L'inganno dell'IMU: l'Italia in cima alla classifica europea della tassazione sugli immobili. Coordinamento Unitario dei proprietari immobiliari. (In Italian) URL Last Checked 20 July 2015.

https://www.senato.it/application/xmanager/projects/leg17/attachments/documento_evento_procedura_commissione/fil es/000/000/133/FEDERPROPRIETA_L_INGANNO_DELL_IMU.pdf

[75] Surgarman, S. (2007) Roles of Government in Compensating Disaster Victims in Catastrophic Risks: Prevention, Compensation, and Recovery. Issues in Legal Scholarship, 10, 1-33, URL Last Checked 15 November 2015. http://works.bepress.com/cgi/viewcontent.cgi?article=1026\&context=stephen sugarman 